\title{
Clarice Lispector: Por uma Poética do Erro
}

\author{
Mayara Ribeiro Guimarães
}

RESUMO: Avaliação do projeto estético elaborado por Clarice Lispector em A paixão segundo G.H. e concretizado em Água viva, fundamentado no diálogo entre pintura e música, no anti-convencionalismo literário, no rebaixamento do poético, na mistura de gêneros e na explicitação do procedimento poético, de modo que a expressão lingüística seja apresentada como problema e objeto de procura do sujeito. Nesse movimento, a reflexão arma o movimento do pensamento sobre si e aponta o paradoxo da tradição literária moderna: a reflexão é ao mesmo tempo caminho para realização do poético e seu empecilho, processo que recupera o diálogo com o Romantismo alemão a partir do movimento de dobra do pensamento sobre si por meio da imaginação e do sentimento, e culmina na Modernidade Literária do século XX.

PALAVRAS-CHAVE: Clarice Lispector; hibridismo; poética.

\begin{abstract}
Evaluation of the aesthetic project elaborated by Clarice Lispector in $A$ paixão segundo G.H. and materialized in Água viva, based on the dialogue between painting and music, in the literary anti-convencionalism, the degradation of the poetics, the mixture of genres and the explication of the poetical procedure, for that the linguistic expression is presented as a problem and a search object of the self. In this movement, the reflection sets the movement of the thought on itself and points to the paradox of the modern literary tradition: the reflection is at the same time a way for accomplishment of poetical and its determent, a process that dialogues with the German Romanticism from the movement of folding the thought on itself by means of the imagination and of the sentiment, and culminates in the Literary Modernity of the 20th century.
\end{abstract}

KEYWORDS: Clarice Lispector, hybridism, poetics.

O movimento de dobra do pensamento sobre si promovendo a reflexão sobre o ato poético, fato que marca a modernidade literária e aparece como tema central de grande parte das obras de autores do século XX e, consequentemente, desta pesquisa, tem origem no Romantismo alemão e implica a escavação do Eu sobre o Eu, realizada por meio da reflexão. A imaginação torna-se protagonista do movimento que proporciona o diálogo entre filosofia e poesia e torna-se a principal arma associada à atividade mental do poeta em busca de uma poesia reflexiva por meio da qual a realidade e as relações do sujeito se transformam em consciência da realidade. As idéias 
desenvolvidas na passagem de século alemão (XVIII - XIX) serão difundidas na literatura inglesa, através de Coleridge e Wordsworth, e em seguida na lírica francesa, desencadeando profundas mudanças no pensamento literário, que servirão como fonte inspiradora e originária do período que assiste ao surgimento da lírica moderna.

Para esta pesquisa, interessa verificar a maneira como o desdobramento do sujeito em eu-sujeito em eu-objeto elaborado pela filosofia fichteana aparece de forma reinventada na lírica moderna, atribuindo à imaginação o papel de articulador central e difusor da mescla de linguagens e gêneros. Esta divisão do sujeito introduz a fragmentação como característica fundamental da modernidade, e impõe a força do vidente como aquele que vê e que é visto e, ainda, a presença do desregramento dos sentidos como a força que gerará o completamente outro de que trata Rimbaud em suas "Cartas do Vidente". Colocado em circulação por meio da poesia, o heterogêneo ganha tratamento especial com as literaturas de vanguarda, especialmente com o Surrealismo e encontra eco no exercício do informe proporcionado pela escrita de Clarice Lispector em A Paixão Segundo G.H. A autora aproxima-se radicalmente de obra quase surrealista com o livro não publicado intitulado "Objeto Gritante", modificando, em seguida, seu projeto literário e estético com a publicação de Água Viva e os textos subseqüentes.

A imaginação, que nasce no sujeito (ideal e infinito), possibilitará a objetivação de diferentes realidades, inclusive novas formas do eu, que se tornará também objeto nesse processo que é real e finito. O sujeito distanciado torna-se espectador, agente crítico e voz racional, distanciado do sujeito-objeto, ator envolvido e agente emocional. Tal procedimento constitui-se como o fundamento da teoria dos fragmentos, elaborada por Friedrich Schlegel como sistema poético- filosófico constituidor da modernidade.

É precisamente a idéia de fragmentação apresentada, no caso de Schlegel, como dilaceramento da consciência, que marcará todo o século $\mathrm{XX}$, período em que o sujeito se decompõe, perde a identidade e passa a se voltar eternamente para a busca de uma reorganização que recomponha inclusive o seu desejo. É possível entender a aprendizagem filosófica de Schlegel como uma tentativa de tornar a filosofia menos tecnicista, de forma a encontrar o fio condutor que a percorre e que se apresenta como 
sendo o mesmo da poesia: a manifestação de algo que não se configura como um princípio sistematizador, ao gosto Kant, mas que está para além de uma forma asseguradora da unidade do saber, algo que implique inclusive a impossibilidade de se delinear esse princípio e que se constitui como uma ausência, uma quebra, um fracionamento, uma falta, um desencaixe necessários à existência e à realização da arte.

Se a crítica kantiana, ao tentar criar um sistema filosófico que apreenda o real e garanta o modo de conhecimento legítimo da relação sujeito-objeto, não consegue encontrar um princípio sistematizador que dê conta do que é incondicionado, desordenado, particular e múltiplo, os filósofos pós-kantianos como Schelling, Kierkegaard e o próprio Schlegel dão continuidade ao trabalho de Kant partindo sempre da ausência que a crítica kantiana não consegue preencher. Para Schlegel, essa ausência repousa no fato de que a fragmentação constitui-se como um fator ou um pendor que a consciência inevitavelmente possui. Assim, portanto, o pensamento de Schlegel caminha no sentido de dar forma à fragmentação constitutiva do ser humano.

Se Kant, de um lado, constitui-se como marco deflagrador do debate filosófico de toda uma geração de filósofos pós-kantianos, de outro, Fichte com sua Doutrina da ciência aparecerá como fonte de inspiração e interlocutor direto de Schlegel e Novalis. No idealismo crítico fichteano, a imaginação apresenta-se como força infinita que interfere e media a formação do processo de conhecimento por meio do enfraquecimento da razão como elemento estabilizador e determinante. No curso de sua autognose, o homem carrega seu lado objetivável em oposição ao seu euirredutível à objetivação. Ao se debruçar sobre si mesmo, o homem nota sua própria fragmentação e somente no movimento de auto-reflexão o eu-sujeito, forçado a olhar para si a partir do olhar lançado de volta pelo seu eu-objeto, poderá se refazer em processo de autoplasmação. E no momento de elaboração da linguagem, observa-se o desabrochar do pensamento sobre o papel como crítica e criação poética ao mesmo tempo. O eu contempla o pensamento se desdobrando sobre si, e nesse instante consegue simultaneamente tornar-se crítico distanciado de si mesmo e ator envolvido emocionalmente. 
Essa condição do sujeito é verificada no romance $A$ paixão segundo G.H. que inicia com a personagem em fase de desintegração da estrutura da subjetividade, seguida de uma imersão no vazio. A primeira frase do livro, a partir do uso do gerúndio, combinado com o verbo auxiliarestar, que marca o aspecto durativo do processo verbal, indica que a ação de despersonalização já estava em curso antes mesmo do início do recorte temporal oferecido pela obra, colocando a personagem no centro de um processo de busca: "estou procurando, estou procurando. [...] Perdi alguma coisa que me era essencial, e que já não me é mais. Não me é necessária, assim como se eu tivesse perdido uma terceira perna que até então me impossibilitava de andar, mas que fazia de mim um tripé estável" (LISPECTOR 1979: 7-8).

Os dois sintagmas verbais que compõem a frase inicial, introduzida por travessões, sugerem que a ação já estava em progresso antes mesmo de ser expressa, o que contribui para a leitura do romance como obra aberta. O sujeito dilacerado entende que sua "montagem humana" oferece-lhe apenas uma estabilidade garantida pelo racional e pelo ordenado. Dividida portanto em um eu-sujeito afundado em acréscimos e um eu-objeto cindido, G.H. inicia um processo de despersonalização, trabalho de destruição da subjetividade esmagadora, rumo ao que chama da "verdadeira humanização" (PSGH 168). Existir na travessia rumo à reconfiguração de uma forma que implique sua forma dessemelhante, revelando seu informe (o sintoma), constitui-se como a grande tragédia de G.H. enquanto existência humana, já que achar a si mesmo é na verdade entregar-se "à desorientação" e à "desorganização" que desmontam a "idéia de pessoa" adquirida com a "terceira perna". "Todo momento de achar é um perder-se a si próprio" (LISPECTOR 1979: 12), resume a narradora. O sujeito só realiza sua despersonalização porque se encontra em fase de liminaridade, distanciado temporalmente de sua organização subjetiva anterior e em processo de constante devir.

Em seguida, a atitude de desdobramento do sujeito em diferentes máscara segue para a lírica francesa de Baudelaire, Rimbaud, e Mallarmé, constituindo o eu cindido e fragmentado, dividido entre o idealismo e o obscurantismo. O desconcerto, a errância do sujeito, o gauchismo. Quando Rimbaud escreve suas famosas Cartas do Vidente, o poeta comenta a própria escrita e aponta a tarefa do poeta vidente: "chegar ao desconhecido pelo desregramento de todos os sentidos." A criação poética implica, 
desde seu início, a ação do caótico, do indeterminado e do obscuro, suspendendo o sujeito de sua consciência e permitindo que o trabalho interno das tripas se realize. Em poucas linhas, Rimbaud reafirma aquilo que se constituirá como imperativo do sujeito moderno: deslocar o eu pensante para o eu pensado e permitir que a imaginação atue como articulador central do heterogêneo.

As Cartas do Vidente convocam a vidência como tarefa de abertura ao "monstruoso" da alma porque "fazer-se vidente" é ao mesmo tempo perscrutar a alma, investigando-a, aprendendo-a, cultivando-a a tal ponto que o vidente chegue deliberadamente ao excesso no próprio desregramento, para que se cruze o limiar das semelhanças em direção ao heterogêneo. $O$ vidente deseja e aceita o máximo do desregramento, tornando-se o doente, o criminoso, o maldito, o fora de si, tudo que se configura como um sintoma. Nesse ponto, despertam-se as forças noturnas do inconsciente por meio das visões oníricas, convocando à cena o trabalho do informe. Quando aí chega, o poeta vê as suas próprias visões, fantasmáticas e, mais que isso, deixa-se ser visto pelo grande inominável, decorrente do próprio excesso. O excesso, por sua vez, suspende a subjetividade e permite que esse outro (o heterogêneo) devolva o olhar. Nessa proximidade, o feio, o baixo, o impuro tornam-se não apenas coexistentes, mas desejados. É a vontade que coloca em um mesmo plano aquelas categorias e as do belo, do alto e do puro. Entretanto, a distância não desaparece quando o desconhecido se apresenta diante do olhar porque o inominável se torna visão para garantir a presença constante de seu afastamento. O objeto olhado torna-se assim "o índice de uma perda" porque nele convivem ao mesmo tempo o que está "sob nossos olhos", mas "fora de nossa visão" (HUBERMAN 1998: 148). O sintoma portanto aparece para provocar tudo o que é resíduo e fragmento, resultando em uma fissura. Essa ínfima cissura é a ruptura necessária para que a abertura da obra aconteça.

Nesse sentido, a paixão narrada pela personagem do romance de 1964 traduz-se pelo amor ao neutro, e este, por sua vez, apresenta-se como o consórcio dos duplos. Observa-se que na construção da obra, a busca por uma forma de existência e de escrita que seja realização desse projeto encontrará eco nas idéias do neutro (o inumano) e do inexpressivo. Para alcançar o inumano, entretanto, é necessário primeiro atingir o núcleo vivo, o que levará ainda à urgência de se inventar uma linguagem que dê forma 
ao inexprimível, que é o próprio informe, imundo, feio e sujo, e que, entretanto, não repita a expressividade tradicional da obra de arte, já que toda afirmação da subjetividade implica a expressão da interioridade em forma ordenada e fixa. Com isso, a narradora de A paixão segundo G.H. percebe que a única forma de expressão do neutro (o próprio excesso) ocorre por meio do inexpressivo. "Quando a arte é boa é porque tocou no inexpressivo, a pior arte é a expressiva" (LISPECTOR 1979: 138), diz a narradora, já que o expressivo se constitui como a forma artística representada pelo sujeito que define o belo, o puro, a ordenação da forma e os valores. O inexpressivo, portanto, só chega por meio do fracasso (da) linguagem. "Só quando falha a construção, é que (se obtém) o que ela não conseguiu" (LISPECTOR 1979: 172), afirma. Em sua travessia pelo indissociável, G.H. descobre que a única linguagem capaz de exprimir o inexpressivo é a da palavra poética. Sendo assim, o real vivenciado na trajetória de G.H. torna-se a realidade do múltiplo e, em vez de tentar dar forma voluntariosa ao informe, a narradora apenas deixa-se existir dentro desse núcleo de forças.

Com a virada do século, surgem os movimentos de vanguarda com criações que privilegiam o ato de destruição, o dilaceramento, a angústia e o vazio, resultados da crise vivenciada pelo mundo. A fragmentação da consciência reflete a convulsão social e leva à fragmentação do corpo e à deformação do real, de modo que o corpo em crise reflita o mundo em desajuste. Nesse universo em que o sujeito perde a identidade, a única saída para reconfigurá-lo se torna em parte a inclusão dos objetos e do mundo no reino do imaginário e do desejo - e desse ponto origina-se o Surrealismo. A arte vê surgir um período de transição, no qual os valores humanos começam a mudar e o objeto começa a ser deslocado (objeto depaysé) até ganhar sua dimensão fantasmática, recuperando a potência imaginária e garantindo a ação do desejo sobre ele, de modo que o real pudesse ser reinventado. A atenção se volta para o detalhe, para o que é momentâneo e a arte moderna começa a privilegiar os poemas fraturados, as justaposições, o fluxo de consciência, a ambigüidade e a ironia trágica que respondem à trama do caos.

Em A paixão... o sujeito reconfigura seu centro quando atinge o neutro, não pela transcendência, mas pela aceitação da falha, do erro e da incongruência como condições imprescindíveis no seu processo de metamorfose. A personagem entende que "não 
transcender" é o "sacrifício" necessário ao ser, já que se busca a ruptura dentro da imanência, e já que a travessia se manifesta como a procura do inumano dentro do humano.

O erro cometido por G.H. consiste em considerar o transcender como algo necessário à salvação do ser, resumindo-se à transgressão através da ingestão do que "não é transcendentável". Apenas depois da manducação a personagem entende que existir no núcleo de força é viver no sem-nome, na reconciliação dos mundos e das coisas e que transcender é apenas mais uma forma de dividir o mundo em categorias opostas. Não-transcender, por sua vez, consiste em existir dentro do indivisível e indiferenciado, do que "não tem nome, nem gosto, nem cheiro" (LISPECTOR 1979: 82), dentro da "própria coisa". O neutro portanto é o nome que se desconhece, a palavra que se ignora e não atinge o expressivo porque é falha para definir o real e o ser. $\mathrm{O}$ reconhecimento da palavra-sem-atributo, aquela que não determina e tampouco designa, provoca, tanto na língua quanto na personagem, deslocamento irreparável por interferir nas "raízes" de uma identidade que se faz também por meio da literatura.

Entretanto, como aponta a crítica clariciana, a partir dos textos da década de sessenta, a escrita da autora começa a sofrer uma modificação estrutural, tornando-se mais híbrida e heterogênea, com eliminação da seqüência temporal do romance tradicional, tendo A paixão segundo G.H. como o marco inicial de tal mudança. Sua obra passa a destacar o contraste entre estilo lírico e coloquial, poesia e fatos domésticos, abstracionismo e figurativismo, além de acentuar o diálogo com outras expressões artísticas como a pintura e a música, resultando em uma narrativa que explicita o processo criativo de composição. Considera-se que uma das razões para tal ruptura, de acordo com o depoimento da própria Clarice, foi a necessidade de renovação artística, intensificada já nos seus últimos dez anos de vida, por conta de seu trabalho como cronista do Jornal do Brasil de 1967 a 1973. Um dos exemplos mais curiosos de tal transformação encontra-se em um datiloscrito intitulado "Objeto gritante", considerado por críticos como Alexandrino Severino como uma das possíveis versões de Água viva e, por outros, como Sonia Roncador, como um projeto estético completamente diferente de qualquer outro texto clariciano e conscientemente abortado pela autora ${ }^{1}$. Aproximando-se de algo como a escrita de um diário ou de uma carta ${ }^{2}$, no 
qual anotações sobre acontecimentos do cotidiano ou reflexões sobre literatura são feitas, incluindo a técnica de montagem e colagem de textos anteriormente publicados e que reaparecerão ainda nas crônicas do Jornal do Brasil, este método se baseia na colagem de textos de diferentes estilos e material heterogêneo: crônicas, diário, poesia, narrativa de caráter fragmentário, sem definição de tema ou forma, apenas em justaposição paratática. Com isso, produz-se uma escrita na qual o objetivo é escrever o que vem à mão, concedendo-lhe caráter fragmentário e a-literário ${ }^{3}$, com efeito de improvisação sem, contudo, deixar de praticar a reflexão sobre a escrita. Para tal, as referências ao ato de criação literária são a tentativa de preservar os rastros do drama e das circunstâncias de produção decorrentes de um combate entre criador e criatura.

Segundo Sonia Roncador, a forma que surge em "Objeto gritante" é a forma do nada para ninguém, isto é, um relato que não apresenta direção, objetivo ou unidade, e tampouco estilo definido ou narrador imaginário. Deseja-se elaborar uma escrita que aconteça de acordo com o pulsar da vida, sem que seja pré-concebida, organizada ou voluntariosa, para que não precipite um sentido. Em "Objeto gritante", a "realidade irrompe no espaço simbólico da linguagem" por meio da descrição de ações concretas do cotidiano da autora em tempo e espaço reais, introduzindo o relato autobiográfico, de modo que se possam indicar as condições da produção do ato da escrita. Assim, intercala, em sistema de composição chamado por José Américo Pessanha de "bricolagem", textos de diferentes gêneros e em variados níveis de linguagem utilizando-se da prática de justaposição paratática que leva à produção de um texto heterogêneo e híbrido. Para Roncador, o fato do texto não buscar unidade interna levaria o "Objeto gritante" a um distanciamento das convenções de "livro".

Por fim, em entrevista concedida ao Correio da Manhãa, Clarice diz querer criar com esse "anti-livro" o efeito de "uma pessoa falando o tempo todo", como se desejasse repetir o fluxo corrente de uma conversa entre a autora e um destinatário desconhecido. Com isso, expõe a nudez do funcionamento de seu texto e questiona as convenções literárias, além da própria obra. Acredita-se que esta modificação radical contém estratégias de criação que se assemelham muito às práticas vanguardistas encontradas, por exemplo, no Surrealismo. 
Se, por um lado, em termos de estrutura formal, Clarice inicia a ruptura com a narrativa tradicional em A paixão segundo G.H., inaugurando a transição para uma fase que acentuará a escrita heterogênea na fusão de textos de diferentes estilos, é somente a partir de Água viva que o texto clariciano radicaliza a nova composição, que não repete a estrutura diarística e em tom confessional de "Objeto gritante", mas que também não se prende aos questionamentos ontológicos de A paixão segundo G.H. É com Água viva que os novos traços se firmam, pois o marco de mudança estrutural havia sido lançado com "Objeto gritante". Clarice Lispector elabora projeto estético em "Objeto gritante", abandona-o para dar espaço a outro projeto estético emÁgua viva, porém carregando as marcas deixadas pela criação do processo iniciado com A paixão segundo G.H. A preocupação em A paixão segundo G.H. com o desvelamento do ser se torna emÁgua viva ocupação com o desvelamento da escrita. Se em "Objeto gritante", como aponta Roncador, verifica-se a técnica da montagem de passagens que intercambiam a narração de acontecimentos do dia-a-dia, em tom coloquial, e o relato de passagens de extremo lirismo, emÁgua viva observa-se a ausência de passagens narrativas e descritivas do cotidiano em nome da presença contínua e ininterrupta de clímaxes, condensados em blocos de imagens que se tornam imagens-questão, acentuando o tom lírico e transformando o texto em um longo poema à vida.

\section{NOTAS}

${ }^{1} \mathrm{O}$ datiloscrito encontra-se no Arquivo Clarice Lispector, situado à Fundação Casa de Rui Barbosa.

${ }^{2} \mathrm{O}$ datiloscrito consiste em um texto de 188 páginas (quase cem páginas a mais do que Água viva) com correções feitas à mão pela própria autora. Sabe-se que o texto sofreu inúmeras alterações, chegando a ter pelo menos três versões diferentes antes de se tornar Água viva, uma delas encontrada no Arquivo Clarice Lispector. Esta versão contém três outros sub-títulos escritos na primeira página, a saber: "monólogo com a vida", "uma pessoa falando" e "carta ao mar[?]". A segunda versão faz parte do acervo do crítico Alexandrino Severino, a quem Clarice pediu para traduzir o texto para o inglês e intitula-se "Atrás do pensamento: Monólogo com a vida".

${ }^{3}$ Nota-se que "Objeto Gritante" seria a tentativa de criar algo completamente sui generis e que talvez chocasse não só o público leitor da autora mas a sua crítica. $\mathrm{Na}$ capa do datiloscrito, manuscrita, lê-se uma reflexão: "Este é um anti-livro. O núcleo é it. Se você considerar isto aqui mais do que carta, fique ciente de que é um anti-livro". 


\section{OBRAS CITADAS}

DIDI-HUBERMAN, Georges. 1998. O que vemos, o que nos olha. São Paulo: Editora 34.

FRIEDRICH, Hugo. 1978. Estrutura da lírica moderna. São Paulo: Duas Cidades.

LISPECTOR, Clarice. 1978. Água Viva. $3^{\mathrm{a}}$ ed., Rio de Janeiro: Nova Fronteira. 1979. A Paixão Segundo G.H. $6^{\text {a }}$ ed., Rio de Janeiro: Nova Fronteira.

MORAES, Eliane Robert. 2002. O corpo impossível. São Paulo: Iluminuras.

PESSANHA, José A. Motta. 1989. "Clarice Lispector: o itinerário da paixão". Remate de Males(Campinas) 9 (maio): 181-198.

RIMBAUD, Arthur. 1980. Cartas do vidente. "Lettre à Paul Demey". Em: RIMBAUD, Arthur; CROS, Charles; CORBIÈRE, Tristan; LAUTRÉAMONT. Oeuvres poétiques complètes. Paris: Robert Lafont. 186.

RONCADOR, Sonia. 2002. Poéticas do empobrecimento - A escrita derradeira de Clarice Lispector. São Paulo: Annablume.

SCHLEGEL, Friedrich. 1997. O dialeto dos fragmentos. Trad., apresentação e notas: Márcio Suzuki. São Paulo: Iluminuras.

SOUSA, Carlos Mendes de. 2000. Clarice Lispector. Figuras da Escrita. Braga: Universidade do Minho/Centro de Estudos Humanísticos.

SOUZA, Ronaldes. 2005. "Fichte e as questões da arte: A filosofia de Fichte e a Poesia Moderna". Em: A arte em questão. Org. Manuel Antônio de Castro. Rio de Janeiro: 7Letras.

SUZUKI, Marcio. 1998. O gênio romântico. Ciência e História da Filosofia em Friedrich Schlegel. São Paulo: Iluminuras. 


\title{
Encontros e Desencontros Críticos com a Modernidade Na Poesia Portuguesa Contemporânea
}

Ida Maria Santos Ferreira Alves (UFF)

\begin{abstract}
RESUMO: Trata-se de apresentar na poesia portuguesa do final do século XX uma perspectiva acentuadamente crítica das práticas diversas que forjaram a modernidade estética portuguesa, estabelecendo-se escritas inquietas e insubmissas. Com um discurso de confronto para compreensão dos mecanismos da tradição e com uma prática de deslocamento das linguagens dominantes, poetas como Joaquim Manuel Magalhães, João Miguel Fernandes Jorge, Nuno Júdice e Adília Lopes dialogam na tensão entre presente e passado cultural, sacralização e dessacralização da poesia, entre a cultura de língua portuguesa e a cultura globalizada e massificadora, interrogando na própria prática do poema o lugar crítico da poesia no mundo contemporâneo.
\end{abstract}

PALAVRAS-CHAVE: poesia portuguesa contemporânea; modernidade; crítica poética

\begin{abstract}
This work presents a sharply critical perspective about aesthetic portuguese modernity in a piece of portuguese poetry from the late 20th century. The confrontation with the tradition and the practice of dominant languages transference. Brief reflection about the poets Joaquim Manuel Magalhães, João Miguel Fernandes Jorge, Nuno Júdice and Adília Lopes, who dialogue in strain between cultural present and past, sanctificiation and desecration of poetry, between the portuguese language culture and the globalized and mass influencing culture. The practice of the poem and the critical place of poetry in the contemporary world.
\end{abstract}

KEYWORDS: contemporary portuguese poetry; modernity; poetic criticism.

Segundo Eduardo Lourenço, em $O$ Labirinto da Saudade, obra hoje mais do que consagrada por suas reflexões sobre a cultura e a literatura portuguesa, ".... tradição não é essa continuidade [da inércia], é a assunção inovadora do adquirido, o diálogo ou combate no interior dos seus muros, sobretudo uma filiação interior criadora, fenômeno entre todos raro e insólito na cultura portuguesa" (1978: 76-77). Ora, a linguagem poética contemporânea (décadas de 70 a 90), em Portugal, comprova que essa "assunção inovadora do adquirido" não é "fenômeno raro e insólito", mas o resultado visível de práticas contínuas e acentuadamente críticas dos tempos diversos que forjaram a modernidade estética portuguesa. 
Se, com efeito, constatamos nessa produção a ausência de discursos radicais de ruptura como os propostos no auge dos projetos modernistas / vanguardistas das primeiras décadas do século XX, há decididamente uma vontade de confronto que deseja compreender e avaliar os mecanismos de uma tradição de modernidade e como esta pode ser deslocada, criando-se dobras críticas da própria cultura estética que a estabeleceu.

Quando falamos de tradição, nomeamos, a partir de uma perspectiva simplificadora, um conjunto de procedimentos e concepções do passado que chegam ao presente. Essa ligação temporal pode se realizar de formas diferentes, ou seja: a) o discurso do presente pode confirmar o do passado e tomá-lo como paradigma, impondo a continuidade passiva, a inércía, numa relação parafrástica; b) o discurso do presente pode rejeitar o do passado e buscar construções originais, numa prática vanguardista; c) o discurso do presente pode retomar o do passado e exercer sobre ele uma ação interrogativa, cruzando perspectivas, estabelecendo novas conexões, demonstrando diferenças, chegando ao novo a partir da transformação do "adquirido", numa ação dialógica. Seja qual for o caminho escolhido, não podemos negar o óbvio: o discurso do presente inevitavelmente deverá se confrontar com o do passado, a ruptura com a tradição, pois uma categoria só tem sentido em relação à outra, como já discutiu Otavio Paz (1984) sobre a tradição da modernidade e suas contradições.

Ora, em poesia, essa problemática parece ser especialmente visível quando é uma linguagem interrogativa sobre sua própria tradição, já que é trabalho verbal sempre atento às configurações de sentidos, às estruturas lingüísticas utilizadas e às realizações poemáticas estabelecidas ao longo do tempo. Pense-se, como um exemplo, esta forma que é o soneto, forma clássica que ainda é continente apreciável de muita poesia contemporânea. Também a respeito disso, escreveu Joaquim Manuel Magalhães, poeta e crítico português: "A poesia [...] é uma globalidade em contínua reformação a partir sempre do todo da literatura que lhe é tradição, de tal forma que em cada poema a globalidade da poesia está em jogo, bem como o próprio devir da poesia a partir desse poema. A tradição poética adquire, sobre o solo dos produtos já existentes, produtos novos que serão o solo de novos produtos e assim por diante" (1982: 28).

Na poesia portuguesa do século XX, a discussão da relação entre diferentes tempos discursiva é fonte de escritas inquietas e insubmissas. Isso começou a ganhar unidade na cultura portuguesa do final do século XIX, quando os diversos níveis da sociedade se defrontaram com uma realidade muito afastada da idealidade histórica desejada e com novos paradigmas estéticos, destacadamente os franceses. $\mathrm{O}$ resultado desse confronto, sem dúvida, provocou, no âmbito literário, a obra de um Cesário Verde, a modernidade de Orpheu e a obra multiforme de Fernando Pessoa, que soube, como nenhum outro em seu tempo (mas talvez Almada Negreiros deva ser lembrado aqui...), instalar-se criticamente na tradição para causar rupturas em diversos níveis, mudando para sempre a face da poesia portuguesa moderna e estabelecendo uma outra fortíssima tradição: a 
do fingimento, com seu pensar / sentir, que ainda hoje, em novo século, ecoa na escrita literária portuguesa.

No caso da poesia que se começa a publicar na década de 70 , conhecedora não só da tradição poética ocidental como especialmente da tradição da modernidade e suas aporias, busca-se definir uma fronteira crítica atenta ao lugar do poético em nosso tempo de incertezas. Já não adianta negar uma tradição e, sim, situar-se nela, dominar seus meios de atuação e, a partir desse domínio, demonstrar as lacunas dos discursos. Assim, a leitura das obras poéticas de poetas como Joaquim Manuel Magalhães, João Miguel Fernandes Jorge, Nuno Júdice e Adília Lopes, por exemplo, encontram-se no mesmo lugar crítico sobre o poético, com perguntas semelhantes: por quê ou para quê escrever ainda hoje? Como ler a literatura os formou? Que cultura é essa que os cerca? Como falar deste tempo contemporâneo, presente de um passado que não se pode esquecer? As obras desses poetas, para além dos diferentes caminhos que seguem, encontram-se nessa tensão entre o presente e o passado, entre a Literatura como Instituição e a escrita literária dessacralizada e dessacralizadora, entre uma cultura em língua portuguesa e um mundo globalizado e massificado. Por isso, são poetas-críticos de seu tempo a interrogar a Poesia, a Cultura, a História e a constituição da subjetividade / identidades no texto e na sociedade contemporânea. Em traços largos, podemos delinear certas práticas determinantes. Uma é questionar o próprio discurso literário, desconstituindo a palavra sacralizada e expondo sua ruína em nossa contemporaneidade, quando o literário tornou-se intensivamente um produto de mercado, uma questão de consumo a envolver escritores, leitores e críticos. Com linguagem irônica e, muitas vezes, melancólica, os poetas se negam a compactuar com as regras do mercado ou a reduzir a escrita poética a prato de fácil degustação. $\mathrm{Ou}$ ironicamente, defendem um regresso ao sentido, uma conquista de leitores pela frugalidade da experiência cotidiana. Dessa visão é prova a escrita de Joaquim Manuel Magalhães, poeta que exerceu, no âmbito da geração de 70 e de 80 , uma função debatedora de grande alcance:

como vou saber se a diferença não há-de ser um pacto novo, um regresso às histórias e às árduas gramáticas da preservação.

[...] voltar à ordem

das mágoas por uma linguagem

limpa, um equilíbrio do que se diz ao que se sente, um ímpeto

ao ritmo da língua e dizer / a catástrofe pela articulada

afirmação das palavras comuns,

o abismo pela sujeição às formas

directas do murmúrio, o terror

pela construída sintaxe sem compêndios.

Voltar ao real, a esse desencanto

que deixou de cantar. (1974: 13) 
Essa perspectiva crítica está igualmente no prefácio assinado por Manuel de Freitas numa pequena antologia intitulada Poetas sem qualidades (2002), em que se defende uma poesia do mais simples, sem sublime ou meditação, uma banalização da palavra poética, a rarefação de uma tradição portuguesa de alto lirismo. Vale a citação mais longa:

O que, de alguma maneira, aproxima estes nomes (e legitimará, porventura, reuni-los num mesmo livro) são, precisamente, as várias 'qualidades' que notoriamente não possuem. Estes poetas não são muita coisa. Não são, por exemplo, ourives de bairro, artesãos tados-mallarmeanos, culturalizadores do poema digestivo, parafraseadores de luxo, limadoes das arestas que a vida deveras tem. Podemos, pelo contrário, encontrar em todos eles um sentido agónico (discretíssimo, por vezes) e sinais evidentes de perplexidade, inquietação ou escárnio perante o tempo e o mundo em que escrevem. Não serão, de facto, poetas muito retóricos (embora à retórica, de todo, se não possa fugir), mas manifestam força - ou admirável fraqueza - onde outros apenas conseguem ter forma ou uma estrutura anémica. Comunicam, em suma; não pretendem agradar ou ser poeticamente correctos. Só é possível falar destes poetas negativamente (e ainda bem): aproxima-os a falta de todas essas qualidades em que os seus contemporâneos se têm revelado pródigos. Por isso estão aqui, a desabrigo, a dizer o que dizem.

Por outro lado, acreditando, apesar de tudo, que a Arte é a garantia da nossa humanidade, há ainda aqueles poetas que refletem sobre seu papel de resistência e fazem dialogar as diversas artes. Buscam a intertextualidade crítica para figurar uma comunidade estética que lhes faça compreender melhor a própria razão de sua escrita e da cultura que os formou. Isso, por exemplo, é uma das direções da poesia de Nuno Júdice, retomando autores clássicos, românticos, simbolistas e modernos, num diálogo inquiridor do "próprio poético". Muitos poemas poderiam ser citados, mas registremos apenas uma estrofe do poema "Lugones", em Meditação sobre Ruínas: "Só a poesia inspira a poesia, / como in vino veritas; / se a metáfora varia / as imagens são pretéritas" (1995: 22).

Outros poetas ainda avaliam a idéia de tradição como passado consagrado e, por isso, recontam a História para estabelecer diferenças e não permitir a imposição de sentidos. Rever criticamente a História é, sem dúvida, um trajeto que recebe especial atenção no panorama da poesia portuguesa contemporânea, já que Portugal vivenciou uma História quinhentista gloriosa e a traumática perda dessa imagem, criando-se um vazio de identidade que, no século XX, com o peso de cinquënta anos de ditadura, acentuou o pessimismo e a melancolia em relação a ser português. Citemos, como exemplo, poetas como João Miguel Fernandes Jorge a recuperar as crônicas históricas de Fernão Lopes e a cruzá-las com o tempo presente, Fernando Assis Pacheco a fazer a crônica da guerra colonial (leia-se o livro Catalabanza, Quilolo e Volta (1976) e nele o poema "A Epopéia" ), Al Berto nos seus livros, Salsugem (1984) e Três Cartas da Memória das Índias (1985) e no conjunto de poemas dedicados a Lisboa em Horto de Incêndio 
(1997). Esses e outros que aqui poderiam ser citados revêem os discursos de uma tradição histórica esgotada e evidenciam rompimentos, fissuras e simulacros.

Também outros poetas questionam o sujeito poético, numa tradição pessoana, discutindo seu lugar na contemporaneidade e o modo como pode se constituir na linguagem. Isso significa não só repensar a subjetividade, a emotividade e as máscaras do poeta, como também desvelar o sujeito oculto na margem, principalmente numa vivência amorosa que não mais corresponde à tradição romântica ou idealista do amor. Assim é recorrente nessa poesia a afirmação mais contudente do discurso homoerótico, enfrentando não só uma tradição social portuguesa como também uma tradição lírica em que o sujeito amoroso se direciona ao feminino ou ao divino. Agora o amigo é claramente o objeto desejado, e a relação amorosa uma desconstrução de imagens. Escreve Joaquim Manuel Magalhães :

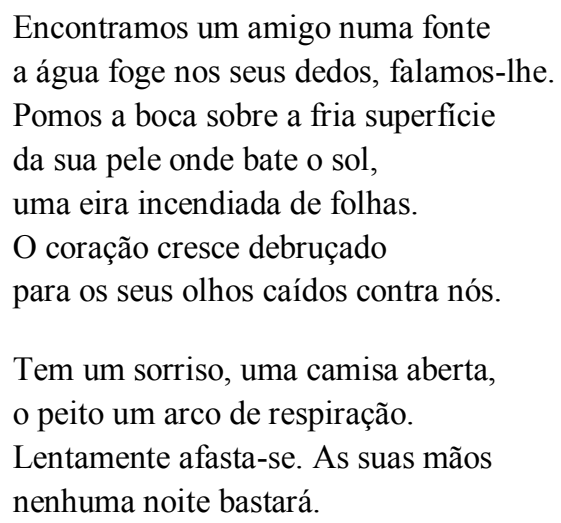

Mas, neste rápido panorama, devemos destacar o trabalho de encontro e desencontro com a modernidade que a escrita de Adília Lopes, com certa recepção brasileira no eixo Rio de Janeiro -São Paulo, vem realizando desde o final da década de 80, com uma escrita dissolvente que afronta os paradigmas literários, sociais e culturais, com aparente ênfase na paródia, no cômico e non-sense. Numa escrita que se vale da sintaxe mais rala, numa poética que se diz do lixo, temos um mosaico de citações, de referências literárias, de jogos de linguagem que corroem os textos literários alheios, constituindo uma desleitura nada inocente por trás da aparente infantilidade e fragilidade de seus versos:

\author{
"Acabou \\ o tempo \\ das rupturas \\ Quero \\ ser \\ reparadora \\ de brechas (2006: 24)
}




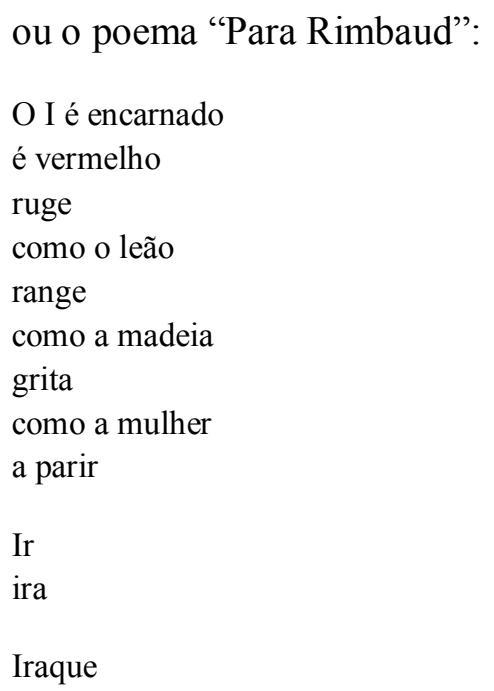

(quando mudei de Física para Românicas, o Professor Pinto Peixoto disse-me que eu ia para a Faculdade de Letras contar quantos "ques" tem a Peregrinação e ensinar às minhas colegas o que é entropia) (2006: 37$)$

Temos, então, nessa diversidade da poética portuguesa contemporânea, escritas que não mais acreditando em "vanguardas", vasculham as "retaguardas" em busca do que foi silenciado ou rasurado, reapresentando a modernidade com o olhar crítico sobre as tradições diferenciadas e rupturas experimentadas. Busca-se não simplesmente assumir "filiações interiores criadoras", mas avaliá-las, transformá-las, constituindo discursos em deslocamento, deslocamento de processos e de efeitos modernos.

\section{OBRAS CITADAS}

AMARAL, Fernando Pinto do. 1991. O mosaico fluido - modernidade e pósmodernidade na poesia portuguesa mais recente. Lisboa: Assírio \& Alvim, 1991.

FREITAS, Manuel de. 2002. poetas sem qualidades. Averno.

JUDICE, Nuno. 1995. Meditação sobre ruinas. Lisboa: Quetzal.

LOPES, Adília. 2002. Antologia. Rio de Janeiro: 7 Letras /Cosac \& Naify. 2006. Le vitrail la nuit - a árvore cortada. Lisboa: \&etc.

LOURENÇO, Eduardo. 1988. O labirinto da saudade. 3. ed. Lisboa: Dom Quixote.

MAGALHÃES, Joaquim Manuel. 1981. Os dois crepúsculos - sobre poesia portuguesa actual e outras crónicas. Lisboa: A Regra do Jogo.

1982. Dylan Thomas consequência da literatura e do real na sua poesia.

Lisboa: Assírio e Alvim. 
ALVES, I. M. S. F. Encontros e Desencontros Críticos com a Modernidade na Poesia Portuguesa Contemporânea 1987. Alguns livros reunidos. Lisboa: Contexto.

MARTELO, Rosa Maria Martelo. 2004. Em parte incerta - estudos de poesia portuguesa moderna e contemporânea. Porto: Campo das Letras.

PAZ, Otavio. 1984. Os filhos do barro. Rio de Janeiro: Nova Fronteira. 


\title{
Fragmentos de uma subjetividade poética: três poemas de amor de Libertinagem, de Manuel Bandeira
}

Wilson José Flores Jr.

\begin{abstract}
RESUMO: O livro Libertinagem ocupa sabidamente lugar de destaque na obra de Manuel Bandeira. Entre os procedimentos característicos à arte moderna aí presentes, destaca-se a autorreferencialidade. Este trabalho analisa alguns pontos de articulação entre os poemas "Porquinho-da-índia", "Teresa" e "Madrigal tão engraçadinho". Neles, a relação entre o discurso amoroso e a perda do objeto amado abre possibilidades de exploração de algumas facetas do sujeito poético, permitindo discutir o modo como infância, biografia e memória articulam-se em poesias cheias de tensões e ambivalências, mais do que conciliações, indicando outro caminho crítico para a leitura do poeta, que problematize certas tendências cristalizadas pela crítica.
\end{abstract}

PALAVRAS-CHAVE: poesia brasileira moderna, Manuel Bandeira, Libertinagem, amor e perda.

\begin{abstract}
In the work of Manuel Bandeira, the book Libertinagem occupies prominent place. The dialogue existent among some poems is one of the characteristic procedures to the modern litterature in the book. This work analises some articulations among three poems: "Porquinho-da-ínida", "Teresa" and "Madrigal tão engraçadinho". The interrelation between the loving speech and the loss of the loved object will be figured as a possibility of exploration of the lyric subjectivity, what will still allow discuss how childhood, biography and memory are articulated in poems full of tensions and ambivalences, rather than reconciliation, indicating another critical path for reading the poet, who problematize certain trends crystallized by the critics.
\end{abstract}

KEYWORDS: modern brazilian poetry, Manuel Bandeira, Libertinagem, love and loss.

É muito comum que a idéia de poesia seja imediatamente associada à expressão de sentimentos, especialmente ao amor. Essa, reconhecidamente, é a visão mais comum, 
a mais entranhada no imaginário coletivo e, portanto, a primeira que qualquer professor interessado em ensinar literatura costuma ter diante de si. Sem negar que o amor é fonte permanente da poesia, reconhecer que o fazer poético não se limita aos arroubos sentimentais dos poetas e que mesmo o amor pode assumir diferentes formas costuma ser um dos primeiros desafios que se enfrenta ao tentar aproximar os alunos da poesia.

Manuel Bandeira, por exemplo, é insistentemente reconhecido como poeta humilde, delicado, sutil. Tais características, sem dúvida, estão presentes em sua obra. Mas digamos que, em certa medida, elas são como o amor para a poesia: revelam um fato genérico que, muitas vezes, ao invés de colaborar para a compreensão dos textos, embota a percepção da particularidade. Em outras palavras: surgem como uma espécie de grande sistema, aparentemente capaz de explicar tudo, mas (ou por isso mesmo) incapaz de dar conta das inúmeras idas e vindas, contradições, ambivalências e tensões que caracterizam o objeto quando olhado a partir de sua singularidade. Isso não quer dizer que as generalizações não são úteis e valiosas. Significa apenas que, quando queremos entender determinado objeto nele mesmo, assim como quando queremos "olhar com olhos livres" (para fazer menção a uma fórmula sintetizada por Oswald de Andrade, em certa medida, cara também a Bandeira) devemos colocá-las sob suspeita, para só então, depois de realizado o mergulho, retomar e tentar repensar o significado das grandes explicações.

Sendo assim, a idéia é analisar alguns pontos de articulação entre três poemas do livroLibertinagem: "Porquinho-da-índia", "Teresa" e "Madrigal tão engraçadinho". Neles, como procuraremos discutir, a relação entre o discurso amoroso e a perda do objeto amado abre possibilidades de exploração de algumas facetas do sujeito poético, permitindo discutir o modo como infância, biografia e memória articulam-se em uma literatura cheia de tensões e ambivalências, nesse que, desde Mário de Andrade, é considerado o momento de "cristalização" do estilo poético de Bandeira.

Como procuraremos discutir, mesmo nesses poemas em que, numa primeira leitura, mal se pode suspeitar de cisão por parte do sujeito lírico, eis que ela aparece em variadas formas, abrindo caminhos para uma exploração crítica que considere as tensões e contradições (tão abundantes e constitutivas - dependendo do ângulo pelo qual se olhe) da obra de Bandeira. 
"Porquinho-da-índia", "Teresa" e "Madrigal tão engraçadinho", apesar da singeleza que os recobre, encerram um intricado jogo de descobertas e frustrações, conquistas e fracassos, que pressupõem, ao mesmo tempo, o reconhecimento e a perda do outro, de forma a delinear experiências que apontam para a configuração mesma do Eu. Experiências extraídas de um passado "vivo", recriado poeticamente, que em sua relação dialeticamente fecunda com o presente vai definindo a forma de o sujeito lírico perceber o mundo e de produzir poesia.

\section{Porquinho-da-índia}

\begin{tabular}{|c|c|}
\hline 1 & Quando eu tinha seis anos \\
\hline 2 & Ganhei um porquinho-da-índia. \\
\hline 3 & Que dor de coração me dava \\
\hline 4 & Porque o bichinho só queria estar debaixo do fogão! \\
\hline 5 & Levava ele pra sala \\
\hline 6 & Pra os lugares mais bonitos mais limpinhos \\
\hline 7 & Ele não gostava: \\
\hline 8 & Queria era estar debaixo do fogão. \\
\hline 9 & Não fazia caso nenhum das minhas ternurinhas... \\
\hline
\end{tabular}

"Porquinho-da-índia" é um dos poemas mais conhecidos de Manuel Bandeira. Seu tom aparentemente despretensioso e despojado, bem como o aproveitamento poético da infância representam algumas das características daquilo que a crítica definiu como o "estilo maduro" do poeta .

Trata-se de um poema que costuma exercer uma forte atração sobre os leitores. Inclusive, em sala de aula, costuma ser dos poemas que mais atrai os alunos, quando superam uma recorrente resistência inicial, resultada da aparente simplicidade do texto, que, se não bastasse, termina com um verso bastante inusitado: “ - O meu porquinhoda-índia foi a minha primeira namorada". Quantos não riem com ar de incompreensão e descrédito quando se deparam com esse desfecho. Aliás, incompreensão e fascínio conferem ao poema algo de enigmático, indicando que o texto possui uma significação forte que, ao mesmo tempo, esconde-se e revela-se em sua simplicidade. 
O motivo central do poema é bastante claro: o eu lírico diz ter ganhado um porquinho-da-índia quando tinha seis anos e afirma que o bicho freqüentemente o frustrava, não se comportando como ele esperava: ao invés do "limpinho" e "bonitinho", o bicho preferia estar debaixo do fogão, aparentando não fazer "caso nenhum das ternurinhas" insistentes e tão bem intencionadas do Eu.

A expectativa inicial do Eu, aliás, repousa em elementos pretensamente objetivos: ele ganhou o porquinho, que é um bichinho de estimação e que, além disso, é pequenininho, fofinho, aparentemente desprotegido. Portanto, o Eu parece inicialmente acreditar que o bicho deveria ser protegido de tudo, estar sempre nos melhores lugares, habitar um mundo previamente preparado para ele pela ternura do Eu. Mas, desde o início, as atitudes do porquinho vão revelando a expectativa inicial como equivocada e fantasiosa.

O poema é composto por dez versos livres, divididos em uma estrofe de nove versos e um verso longo final, isolado do corpo da estrofe. Os do is primeiros versos apresentam um tom de satisfação (a lembrança do presente), enquanto o $3^{\circ}$ e o $4^{\circ}$ versos contrastam com os anteriores, iniciando uma seqüência marcada por certa frustração, que define os versos intermediários:

Que dor de coração me dava

Porque o bichinho só queria estar debaixo do fogão!

Já o último verso, por sua vez, contrasta a frustração dos anteriores com um tom que novamente sugere satisfação, agora marcado por uma certa nota confessional:

- O meu porquinho-da-índia foi a minha primeira namorada.

Quanto ao ritmo, Mário de Andrade, em ensaio famoso ("Poesia em 1930"), afirma que Libertinagem "é o livro mais indivíduo Manuel Bandeira de quantos o poeta já publicou". E comenta sobre a constituição rítmica dos poemas do livro: "ritmo todo de ângulos, incisivo, em versos espetados, entradas bruscas, sentimento em lascas, gestos quebrados, nenhuma ondulação. A famosa cadência oratória da frase desapareceu. Nesse sentido, Manuel Bandeira é o poeta maiscivilizado do Brasil: não só pelo abandono total do enfeite gostoso, como por ser o mais... tipográfico de quantos, bons, possuímos". Para exemplificar seu argumento, Mário cita "Porquinho-da-índia", 
e, para designar o ritmo do poema, faz uso, basicamente, das oposições suave intratávele suave-áspero .

Note-se que tais oposições configuram também o próprio porquinho, tal como o eu lírico o apresenta. Vejamos: não há reciprocidade entre as ações e intenções do Eu e as do bicho. Se o Eu claramente o deseja - e deixa isso insistentemente claro no poema - não há da parte do bichinho qualquer ação clara de correspondência. Ele aparece ao Eu como suave e intratável, doce (na medida em que desejável) e áspero(na medida em que indiferente). O movimento parece unilateral e falhado: o objeto amoroso, já em si mesmo improvável (um exótico bichinho de estimação), foge-lhe e não corresponde às suas investidas e ao seu carinho. Some-se a isso outro fato que dificulta ainda mais a correspondência e a equivalência entre os "sujeitos" envolvidos: sendo um presente, o porquinho é um objeto possuído, ou seja, o Eu é, a rigor, seu dono .

Assim, na medida em que a suavidade e ternura convivem no poema com a frustração e o fracasso, outra analogia com o ritmo parece possível, perfazendo, também no nível semântico, um "ritmo todo de ângulos, incisivo, em versos espetados, entradas bruscas, sentimento em lascas, gestos quebrados".

Note-se ainda uma importante oposição sonora: a do universo sonoro do inho em contraste com o do ão. A sonoridade dos versos 2, 6 e 9 é marcada pela assonância de $i$ (tinha, seis, ganhei, porquinho, índia, limpinho, ternurinhas etc.), que reponta em todo o poema, mas com força muito menor nos versos 3, 4, 7 e 8, nos quais, em especial nos dois últimos, é suplantada pela sonoridade fechada do ão (coração, fogão, não). A essa oposição sonora, podemos associar uma sucessão de outras oposições, a exemplo de sim $X$ não; íntimo $X$ cerimonioso; pequeno $X$ grande; criança $X$ adulto; mas também vazio $\mathrm{X}$ cheio; e falha $\mathrm{x}$ realização. Vejamos alguns desdobramentos.

A primeira oposição ( $\operatorname{sim} X$ não) pode ser entendida como o conflito central do poema, discutido anteriormente: o eu lírico deseja o bichinho, mas seus esforços são por ele solenemente ignorados. Deseja o "sim", mas não consegue nada além do "não".

Já as três oposições seguintes (íntimo X cerimonioso; pequeno $\mathrm{X}$ grande; criança $\mathrm{X}$ adulto), ligam-se a elementos decisivos da construção literária do texto. "Porquinhoda-índia" inicia-se com um procedimento comum a vários poemas de Bandeira ${ }^{4}$ : uma 
espécie de "fórmula de abertura, constituída por uma oração subordinada temporal, introduzindo a narração de uma situação ou cena parecida às da prosa de ficção" ${ }^{5}$.

No caso de "Porquinho-da-índia", as imagens ligam-se ao espaço interior e protegido da casa, sintetizado nas oposições sala X cozinha e "lugares mais bonitos, mais limpinhos" X "debaixo do fogão". Não há qualquer referência a espaços exteriores, abertos, vinculados ao mundo da rua; as imagens fixam representações interiores, mas de dois tipos diferentes: a sala como o espaço arrumado, limpo e bonito, e, por isso, construído para ser visto, oposto ao espaço efetivamente íntimo da casa, ligado à vida concreta. E aí encontramos outros desdobramentos da oposiçãoíntimo $X$ cerimonioso: ao tentar oferecer o melhor ao bicho, o Eu, que o deseja íntimo, oferecelhe tratamento, digamos, cerimonioso, como que para lhe conquistar o amor, tratamento recusado pelo porquinho, que, assim, rejeita os apelos de intimidade do eu, comportando-se ele mesmocerimoniosamente em relação às investidas do eu, mas intimamente em sua relação com a casa, a família e a vida.

A própria tensão na fatura poética entre lirismo espontâneo e tratamento prosaico, aludida acima, vincula-se ainda à oposição íntimo $X$ cerimonioso em outro nível. Parece que em "Porquinho da índia" podemos distinguir um "espaço humanizado", um espaço construído em função da personagem. No poema, encontramos um Eu situado no passado a quem aconteceu ganhar um bichinho de estimação. O eu lírico, situado no presente, apresenta-nos esses acontecimentos metamorfoseado também numa espécie de narrador em comunicação direta, em certa medida, confessional e íntima, com o leitor. Além disso, o uso constante e poeticamente eficaz dos diminutivos dá ao Eu lírico (presente) uma expressão próxima à do Eu do passado, articulando-se no texto uma "narração" ao mesmo tempo distinta (uma vez que realizada pelo adulto) e conectada à experiência do passado (na medida em que procura mimetizar os sentimentos da criança). Esse jogo entre adulto e criança é responsável pelo sentimento de mútua implicação entre presente e passado, da representação da experiência do passado como "memória viva", mas também pelo sentimento de resignada aceitação da falha e do fracasso que brota do poema. $\mathrm{O}$ adulto já não se desespera como a criança o fazia e tem diante do quadro uma atitude muito mais complacente consigo mesmo. Mas, a despeito da intratabilidade do porquinho, da 
relação de posse que define o encontro entre eles e do fracasso do sujeito lírico, é esse bichinho que foi eleito por ele como primeira namorada. Nesse trajeto, obviamente, há um envolvimento que se desenha de maneira muito particular.

Toda a expressão do poema, como se nota imediatamente numa primeira leitura, centra-se no Eu e no porquinho. De fora, só aparece a referência imprecisa do "ganhei" que não apenas aponta para outro (ou outros) para além da relação central, como também parece indicar outra coisa: o Eu não diz ter pedido nem exigido, mas ganhado o porquinho, ou seja, o verbo aponta para uma ação realizada por outro que teve a iniciativa de escolher e dar o presente, indicando certa passividade inicial do sujeito.

O envolvimento do Eu se modificará e se ampliará na seqüência dos versos, na medida em que, como vimos, o porquinho não reage da maneira como o sujeito lírico parece desejar. Daí a transformação decisiva (ainda que falhada, pois não se consuma): do "ganhei" do início, chega-se à (escolha da) "namorada" no final, ou seja, da situação passiva à ativa, do presente à escolha. E uma escolha tanto mais subjetiva, tanto mais própria apenas ao $\mathrm{Eu}$, que é feita de maneira unilateral, pois não encontra (nem poderia?) correspondência no bichinho. Em outras palavras: parece possível afirmar que a escolha é realização e é falha, ou realização que se faz na falha.

Assim, se a maior parte do poema (sete dos dez versos) expressa situações de frustração e surpresa, são essas mesmas situações que acabam por deslocar as crenças iniciais do Eu, obrigando-o a repensar suas expectativas e sua visão do mundo. O poema seria, deste ponto de vista, uma representação do encontro com o outro, da descoberta do outro - e de um outro intratável - que marcará a experiência amorosa do Eu, como podemos observar em outro poema de Libertinagem.

\section{Madrigal tão engraçadinho}

Teresa, você é a coisa mais bonita que eu vi até hoje na minha vida, inclusive [ o porquinho-da-índia que me deram [ quando eu tinha seis anos.

Composto por apenas um verso bastante longo, "Madrigal tão engraçadinho" configura-se como uma declaração de amor singela, infantil e, ao mesmo tempo, intensa 
e absolutamente pessoal (afinal, que outra "mulher" poderia receber o mesmo elogio e que outro sujeito poderia fazê-lo?), centrada na comparação de Teresa com o porquinho.

Essa comparação, que a princípio soa despropositada e estranha, parece trazer importantes sugestões sobre o porquê de o porquinho ter sido alçado pelo Eu à condição de sua "primeira namorada". Passado e presente aparecem, novamente, implicados: é a infância (o porquinho) que define a escolha do objeto amoroso; é a experiência infantil que traça certas possibilidades e limites; é ela que, por assim dizer, constrói as linhas mestras do desejo e da sensibilidade do sujeito. Mas é o presente, a experiência atual (Teresa) que permite ao sujeito retomar, redimensionar e reinterpretar a experiência do passado, integrando-a, agora, em um novo registro que passa a definir a percepção e a memória do Eu lírico ${ }^{6}$.

E será ainda outro poema do livro que nos permitirá desenvolver essas relações.

\section{Teresa}

A primeira vez que vi Teresa

Achei que ela tinha pernas estúpidas

Achei também que a cara parecia uma perna

Quando vi Teresa de novo

Achei que os olhos eram muito mais velhos que o resto do corpo

(Os olhos nasceram e ficaram dez anos esperando que o resto do corpo nascesse)

Da terceira vez não vi mais nada

Os céus se misturaram com a terra

E o espírito de Deus voltou a se mover sobre a face das águas.

Teresa, tal como o porquinho-da-índia, também não corresponde, originalmente, às expectativas do Eu nem às expectativas mais comuns a respeito do despertar do amor. Ao invés de um imediato reconhecimento, do "amor à primeira vista" celebrado pelo senso comum e por certa tradição literária (sem contar o enorme sucesso da fórmula em várias formas de subliteratura e da cultura de massa), o Eu estranha radicalmente a Teresa em seu primeiro encontro, a ponto de considerar sua aparência desagradável. O "retrato", um pouco à la manière de la pintura moderna, apresenta uma mulher desconjuntada, metonimicamente esquartejada em partes cuja percepção pelo sujeito é fragmentária, senão repulsiva ("pernas estúpidas", "a cara parecia uma perna"). 
O ritmo dos versos é ríspido e direto, como uma sentença de condenação. Cada verso apresenta um período que se encerra em forte pausa (como se houvesse uma vírgula no final do primeiro e pontos no final dos dois outros versos). A secura sugere uma percepção, digamos, sem fissuras, ou seja, convicta do que vê e de que não gosta do que vê. Percepção fragmentária, incômoda e, nesse primeiro momento, convicta.

$\mathrm{Na}$ segunda vez, o estranhamento cede lugar a uma espécie de descoberta, ou melhor, à percepção de certo mistério: o sujeito parece ver em Teresa algo que the chama a atenção, que o encanta, mas que ele ainda não é capaz de definir ou entender. Os versos se alongam, substituindo a rispidez seca e convicta dos versos da primeira estrofe, por um tom mais intuitivo, marcado pela curiosidade e por definições vagas. $\mathrm{O}$ contraste entre "A primeira vez que vi Teresa" e "Quando vi Teresa de novo" aponta para a mesma direção. Ao tom direto do verso da primeira estrofe opõe-se o tom suave e como em suspensão do verso da segunda estrofe, que anuncia algo novo, mas que ainda não aconteceu de todo. É uma nova percepção, mas ainda indecisa quanto a si mesma.

Essa atmosfera de descoberta e suspensão será superada na estrofe seguinte. O verso "Da terceira vez não vi mais nada" se, por um lado, apresenta algo do tom direto do primeiro verso do poema, por outro, o faz agora em chave terna e não mais condenatória. A convicção muda de forma: não mais a certeza de não ter gostado, mas a experiência turbulenta e arrebatadora que toma conta do sujeito. Os versos finais retomam de maneira clara e quase literal os três primeiros versículos do livro de Gênesis:

No princípio, Deus criou os céus e a terra. A terra estava informe e vazia; as trevas cobriam o abismo e o Espirito de Deus pairava sobre a face das águas. Deus disse: "Faça a luz!" E a luz foi feita.

Ou seja, os versos "Os céus se misturaram com a terra/ E o espírito de Deus voltou a se mover sobre a face das águas" laçam o sujeito lírico como que num momento pré-criação, anterior ao tempo e a tudo que existe. Anterior, portanto, à distinção, ao trabalho divino de discriminar, de separar as coisas dando a elas forma para começar a preencher o vazio do abismo. Ambos os versos são marcados por verbos de movimento (misturar, voltar, mover) e de movimento intenso, violento. Assim, o momento da "plenitude" final é turbulento, não inspira ou traz sossego, mas arrebata, transtorna, rompe os limites entre o eu e o outro, entre as coisas, colocando-as 
todas no estado de indistinção próprio à paixão. E paixão, como se sabe, é sofrimento e não paz; é turbulência e não bonança. Ou seja, há uma realização, há uma presença, uma conquista, mas não há sossego. Intui-se aqui "a paixão dos suicidas que se matam sem explicação", , mas não o repouso que poderia advir da realização do amor.

Portanto, se retomarmos a relação com "Porquinho-da-índia", em "Teresa" encontramos a realização amorosa, uma vez que já não estamos apenas na unilateralidade que marcava o primeiro poema. Mas o gosto, digamos, pelo "bizarro", pelo estranho, pelo não convencional, assim como a intensidade e a turbulência das emoções, aproximam os dois objetos amorosos.

No entanto, vale enfatizar algo. Como se sabe, "Teresa" é uma paródia de "O adeus de Teresa", de Castro Alves. Portanto, Teresa, menos do que nome de uma mulher específica e concreta por quem Manuel Bandeira em pessoa tenha se apaixonado, é uma imagem poética, um construto literário, um nome que encontra ecos na tradição literária brasileira, o que não apenas não diminui seu "valor" como o multiplica, uma vez que é alçado poeticamente ao universal, ao invés de permanecer na particularidade confessional. De outra parte, se tal afirmação é evidente no caso de Teresa ela é curiosamente muito menos clara no caso do porquinho-da-índia esteticamente rememorado no poema.

Daí advém uma hipótese para a leitura de Bandeira. Considerando a discussão realizada, não parece excessivo afirmar que o poeta construiu para si uma persona literária, freqüentemente associada sem muita mediação à pessoa concreta de Bandeira, com características bastante conhecidas: timidez, humildade, despojamento, espontaneidade, domínio do subsconsciente sobre a razão etc. Mas, ao contrário do poeta de "circunstâncias e desabafos", reluz uma dimensão conhecida, mas, às vezes, obliterada pela outra: a de uma sistemática construção literária. Desse ponto de vista, a constituição do Eu lírico ocorre simultânea e concomitantemente à construção do estilo poético. É a consolidação do estilo que consolida o Eu, assim como é a constituição do Eu que institui o estilo. Nesse sentido, memória e literatura parecem ser, em Bandeira, indissociáveis: é como se o poeta houvesse, no processo de cristalização de seu estilo, "recriado" para si sua memória, reconstruindo-a enquanto literatura. E esse processo 
não ocorreu de forma unívoca, de forma a constituir, digamos, um Eu lírico monolítico, comum a todos os poemas, como parecem sugerir algumas leituras.

A hipótese é de que o trabalho poético realizado a partir da memória responde a um processo identificado por Otto Maria Carpeaux e comentado da seguinte maneira por Bandeira no último parágrafo do Itinerário de Pasárgada:

Otto Maria Carpeaux uma vez a meu respeito, disse, com certeira intuição, que no livro ideal em que ele estruturaria a ordem de minha poesia, esta partia 'da vida inteira que poderia ter sido e que não foi' para outra vida que viera ficando 'cada vez mais cheia de tudo'. De fato esse é o sentido profundo daCanção do vento e da minha vida.

Só para relembrar a última estrofe do poema citado:

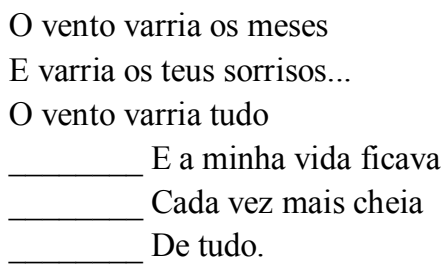

O comentário de Carpeaux é lapidar: a obra de Bandeira passaria por um processo que se inicia "na vida inteira que poderia ter sido e que não foi", marca da melancolia dos primeiros livros - e de alguns de seus poemas ao longo de toda sua obra - e se completa, ou se consuma poeticamente, numa "vida que foi ficando cada vez mais cheia de tudo". Mas, digamos, de um tudo recriado a partir do nada, a partir do que não foi. Um tudo recriado a partir do vazio deixado pelo vento que tudo varreu. Percepção próxima a de Sérgio Buarque de Holanda, para quem, em Bandeira, "as prisões e naufrágios da vida deixam de ser uma limitação para se transformarem em um motivo de enriquecimento. E a poesia pode jorrar em sua liberdade infinita...", afirmação que o historiador complementa com a mesma estrofe que acabamos de citar.

Levando-se isso em consideração, a "primeira namorada" pode ser pensada como uma afirmação, como um "sim", mas que se constitui contraditoriamente a partir 
da negação e da perda. É um "tudo" construído a partir de ausência: não apenas o porquinho há muito deixou de existir; não apenas o bicho não correspondeu aos anseios do menino, como sua lembrança é recriação: é a "vida que vai ficando que vez mais cheia de tudo" que cria sua própria mitologia literária.

Se a "infância feliz" é uma construção feita retroativamente pelo adulto, a partir de fragmentos de memória, de boa dose de autocondescendência e de alguma criatividade, como afirma Freud, talvez se esteja aqui diante de um procedimento comum que, deixando o campo simples da memória ou da história individual, alçou-se a um processo consciente de construção poética. Assim, se memória e literatura já não se distinguem na obra de Bandeira, a compreensão de sua poesia parece exigir que se radicalize, por assim dizer, a análise da constituição do estilo do poeta, pensando seus poemas - mesmo o seu "autobiográfico" Itinerário de Pasárgada -menos como “confissão" pessoal ou relato "histórico" e mais como expressão de certa construção que o poeta fez de si, e que, portanto, mais do que memória, "circunstância e desabafo" como insiste o próprio Bandeira - é, conscientemente, literatura.

Caso as hipóteses aqui levantadas se sustentem, deve emergir desta discussão uma imagem do poeta um pouco diferente daquela que a crítica tendeu a consagrar: além do lirismo inconsciente ou instintivo, um projeto poético que vai se tornando cada vez mais consciente ao longo de sua produção (e que tem em Libertinagem um consensual ponto de inflexão); ao invés da humildade, um grande conjunto de ambivalências que, talvez, mais do que conciliar, radicaliza, na simplicidade aparente da linguagem, as tensões que os poemas movimentam e pelas quais são movimentados.

\section{Referências}

ANDRADE, Mário de. A poesia em 1930. Aspectos da literatura brasileira. 6.ed. São Paulo: Martins, 1978.

ARRIGUCCI JR., Davi. Humildade, paixão e morte. 2.ed. São Paulo: Companhia das Letras, 2003.

. O humilde cotidiano de Manuel Bandeira. In Enigma e comentário. São Paulo: Companhia das Letras, 2001. 
A beleza humilde e áspera. In $O$ cacto e as ruínas. 2.ed. São Paulo: Editora 34, 2000.

BANDEIRA, Manuel. Estrela da vida inteira. 20.ed. Rio de Janeiro: Nova Fronteira, 1993.

. Itinerário de Pasárgada. 3.ed. Rio de Janeiro: Editora do Autor, 1966.

. Poesia completa e prosa: volume único. Rio de Janeiro: Nova Aguilar, 1996.

HOLANDA, Sérgio Buarque de. Trajetória de uma poesia. In BANDEIRA, Manuel. Op.cit, 1996.

FREUD, Sigmund. Conferência XXI. Edição standard das obras psicológicas completas de Sigmund Freud. Vol. XVI. Rio de Janeiro: Imago, 1996.

TANIS, Bernardo. Memória e temporalidade: sobre o infantil em psicanálise. São Paulo: Casa do Psicólogo, 1995.

\section{NOTAS}

$1 C f$. Arrigucci Jr., Davi. Humildade, paixão e morte. 2.ed. São Paulo: Companhia das Letras, 2003; e O humilde cotidiano de Manuel Bandeira. Enigma e comentário. São Paulo: Companhia das Letras, 2001.

2 Essas oposições estão presentes em outros poemas de Libertinagem. O exemplo mais evidente é, sem dúvida, "O cacto", cujo título já traz uma imagem de aspereza, e cujo último verso é bastante elucidativo: Era belo, áspero, intratável. A respeito desse poema, ver Arrigucci Jr., A beleza humilde e áspera. $O$ cacto e as ruínas. 2.ed. São Paulo: Editora 34, 2000.

3 A exploração desta relação (amor-posse) remete ao universo patriarcal-escravista brasileiro, presente na obra de Bandeira, ainda que de modo pontual e, algumas vezes, velado, submerso em outras representações. Não desenvolverei neste artigo esta relação que fica para um desdobramento do presente trabalho.

4 No mesmo texto, para mostrar a recorrência desse procedimento, o crítico cita "Poema só para Jaime Ovalle", "Soneto inglês n ${ }^{\circ}$ 1", "Consoada", "Peregrinação" e "Maçã", poemas de livros diferentes, mas, como ele mesmo ressalta, poderia ter apontado outros, como o próprio "Porquinho-da-índia" que estamos analisando aqui.

5 ARRIGUCCI JR., A festa interrompida, In Humildade paixão e morte, op.cit., p.204. 
6 Aqui a referência é o conceito de a posteriori da teoria de Freud, central para a discussão psicanalítica e retomado pelo autor ao longo de toda sua obra. Comentando esse conceito, o psicanalista brasileiro Bernardo Tannis afirma que "o que é realmente significativo quanto ao funcionamento do psiquísmo é a coexistência temporal do presente e do passado, na qual o presente deixa de ser presente na medida em que é vivido e experienciado a partir de outro lugar (temporal e espacialmente falando) e o passado não somente evocável mas potencialmente eficaz. Mas de onde advém sua eficácia no presente? A inscrição não metabolizada possui um poder de transferência para o presente. É condição de possibilidade que detona em determinada experiência. [...] só no a posteriori será possível reconstruir o sentido da representação latente". (TANIS, Bernardo. Memória e temporalidade: sobre o infantil em psicanálise. São Paulo: Casa do Psicólogo, 1995.; p.13; grifos do autor). Some-se a isso um trecho da Conferencia XXI, "O desenvolvimento da libido e as organizações sexuais", na qual Freud afirma: "O desenvolvimento da libido, para dar ao assunto toda a concisão possível, tem dois objetivos: primeiro, o abandono do auto-erotismo, logo, a substituição do corpo da própria criança por um objeto externo; e, em segundo lugar, a unificação dos diversos objetos dos instintos separados e sua substituição por um único objeto. Naturalmente isto só pode ser realizado se o objeto, de novo, for um corpo total, semelhante ao próprio sujeito" (FREUD, Sigmund. Vol. XVI da Edição standard das obras psicológicas completas de Sigmund Freud. Rio de Janeiro: Imago, 1996; p.333). Pensando nos poemas que estamos analisando, se aos seis anos, a escolha de objeto por parte do sujeito lírico se encontra realizada e unificada, incipientemente, na figura do bichinho de estimação, é claro que, como apontado na citação acima, essa primeira descoberta, essa primeira escolha de objeto, se já aponta os limites e possibilidades do desenvolvimento futuro, ainda precisa, digamos, ser refinada, de forma a encontrar "um corpo total, semelhante ao próprio sujeito". É isso o que, segundo a discussão realizada aqui, ocorreria com a entrada em cena de Teresa. Fica o registro desta nota, ainda que incompleto e excessivamente rápido, uma vez que, parece-me, a exploração da questão que se propõe aqui implicará certo trato com a psicanálise, que, aqui, foi apenas esboçada.

7 Verso final de "O último poema", de Libertinagem. 


\title{
O Imaginário do Céu e do Inferno em Carlos D. de Andrade
}

\author{
Enivalda Nunes Freitas e Souza (UFU)
}

RESUMO: Mesmo quando a poesia de Drummond evoca a fé provinda da tradição judaico-cristã, pode-se afirmar que o poeta mantém-se alheio à inquietação religiosa, desenvolvendo uma postura de união dos contrastes permeada pela ironia e pelo humorismo que lhe são peculiares. É o que se verifica no seu poema "Casamento do céu e do inferno", de Alguma poesia, por meio de símbolos, imagens e mitos. Neste ensaio, pretende-se conjugar o imaginário deste poema ao ideário estético do Modernismo e sua atitude de consagração das formas dissonantes.

PALAVRAS-CHAVE: Drummond; Céu e inferno; Milton, Blake.

ABSTRACT: Even when the poetry of Drummond evoques the faith from jewishchristian tradition, one can assume that the poet is apart from any religious anxiety. $\mathrm{He}$ develops although an attitude which joins contrasts, and his poetry is transversed by a proper irony and sense of humour. That's one can see in his poem "Casamento do céu e do inferno" ("Marriage of Heaven and Hell"), from the book Alguma Poesia (Some Poetry), in which the poet uses symbols, images and myths. The aim of this paper is to unite the imaginary of the above poem to the aesthetical ideas of the Modernism within its attitude of consecration of the dissonant forms.

KEYWORDS: Drummond; Heaven and Hell; Milton; Blake.

Escrito entre 24 e 30, Alguma poesia ainda ostenta caráter de batalha, pois pode ser lido como um combate ferrenho travado entre as concepções clássicas de mundo e de poesia e o mundo moderno, cuja linguagem revela as sete faces do indívíduo do século XX. Neste livro, ainda vive-se o tempo em que "o anjo bom" quer matar "o anjo mau" e jogar "seu corpo no rio", conforme versos do "Poema da purificação", o último de Alguma poesia. $O$ anjo mau vencido na batalha tinha um sangue "que não descorava", tão forte que todos os peixes morreram. Contudo, aparece outro anjo, iluminado, para clarear o mundo e pensar "a ferida do anjo batalhador." Mas, afinal, o que anunciam, o que fazem tantos anjos na terra de Drummond? Como sabemos, é o anjo torto que abre Alguma poesia; mas quem encerra é um anjo iluminado, que vem para pensar a ferida do anjo batalhador. No penúltimo poema de Alguma poesia, Jesus 
dorme "sonhando com outra humanidade", cansado de tanto pedido. Desta forma, tendo anjos bons e anjos maus livre trânsito em sua poesia, não é difícil perceber que o poeta, mais do que afastar as forças contrárias, promove uma comunhão entre as contradições, um verdadeiro "casamento do céu e do inferno", como havia feito o poeta William Blake, dentro do mesmo espírito de inquietação e iconoclastia de que se reveste Drummond nestes tempos combativos do Modernismo. Acredito que os anjos de Drummond anunciam um trajeto mais livre para o homem, como também reforçam o anseio libertador da poesia da década de 20. Para engendrar esse caráter revolucionário comportamental e estético, não se pode perder de vista o gauche de Drummond ou o Satã de William Blake e de John Milton. Contudo, é um equívoco pensar que Drummond sela pacto com Satã, tampouco que se compromete com Deus. No fundo e no fim do poema, lá estão o humor e a ironia isentando o poeta de qualquer partidarismo comprometedor. Em poemas como "Infância" e "No meio do caminho", o poeta funde novos e velhos estilos de vida e de poesia, espantando o tédio e o estabelecido, e instaurando uma nova ordem.

O poema "Casamento do céu e do inferno", o terceiro de Alguma poesia, é suficiente para provocar algumas reflexões sobre o poeta itabirano e sobre aqueles anos decisivos para a poesia:

\title{
CASAMENTO DO CÉU E DO INFERNO
}

\author{
No azul do céu de metileno \\ a lua irônica \\ diurética \\ é uma gravura de sala de jantar. \\ Anjos da guarda em expedição noturna \\ velam sonos púberes \\ espantando mosquitos \\ de cortinados e grinaldas. \\ Pela escada em espiral \\ diz-que tem virgens tresmalhadas, \\ incorporadas à via-láctea, \\ vaga-lumeando... \\ Por uma frincha \\ o diabo espreita com o olho torto. \\ Diabo tem uma luneta \\ que varre léguas de sete léguas
}


e tem o ouvido fino

que nem violino.

São Pedro dorme

e o relógio do céu ronca mecânico.

Diabo espreita por uma frincha.

Lá embaixo

suspiram bocas machucadas.

Suspiram rezas? Suspiram manso, de amor.

E os corpos enrolados

ficam mais enrolados ainda

e a carne penetra na carne.

Que a vontade de Deus se cumpra!

Tirante Laura e talvez Beatriz,

o resto vai para o inferno.

(Carlos Drummond de Andrade. Alguma poesia)

De súbito, a objetivação, o caráter "anti-romântico (um céu de metileno, um retrato de lua). Penso que desde já se estabelece o princípio do casamento entre o "baixo" e o "elevado", melhor, entre duas ordens que se supõem distantes e antagônicas: a lua é deslocada da imaginação para tornar-se uma paisagem morta. Nesse deslocamento ela perde sua aura idealizada, intangível, e se converte num simulacro (gravura) desprovido de qualquer traço sentimental. A lua sem subjetividade, sem emoção. A lua desce ao cotidiano, não mais alimenta paixões (quase sempre platônicas) nem consola com sua solidão as almas inquietas: a lua (antes, tão metafísica) faz-se enfeite do espaço que serve à necessidade da mais prosaica materialidade humana: a sala de jantar. A lua vem abaixo e compõe o prosásmo do diaa-dia. De forma contundente, esses versos ainda exalam combate, estranhamento, choque, e ostentam, claramente, uma postura arrivista, sinal de que a "ordem" ainda é ditada por outras leis que não sejam as da liberdade, da reflexão, da criatividade, da materialidade. Neste momento, as formas modernas ainda não estão sedimentadas, ainda é preciso criar um céu de metileno e uma lua irônica/diurética.

$\mathrm{Na}$ segunda estrofe, "anjos da guarda em expedição noturna" guardam sonos púberes espantando mosquitos. Há um solavanco na passagem da primeira para a segunda estrofe: o poeta sai da sala de jantar e penetra no quarto, sobrepondo à "lua 
irônica" "anjos da guarda" e "sonos púberes". Esta aparente descontinuidade imagética exemplifica a observação feita por Mário de Andrade sobre Alguma poesia: "Poesia sem água corrente, sem desfiar e concatenar de idéias e estados de sensibilidade, apesar de toda construída sob a gestão da inteligência. Poesia feita de explosões sucessivas. Dentro de cada poema as estrofes, às vezes os versos, são explosões isoladas" (1992: XXXVII).

Entrecruzando estas "explosões sucessivas", estão a inteligência e a sensibilidade de Drummond, segundo conclusão de Mário de Andrade. Assim é que após "a lua irônica/diurética" vêm os "sonos púberes" e, ao final, percebe-se que não há “explosões isoladas". Sob patrulhamentos e vigilâncias, as virgens (os sonos púberes) parecem repousar em paz. Se tomarmos, como tantas vezes o fazemos nas leituras de poesia, esses "sonos púberes" como metonímia (???) da virgem, poderíamos reconhecer aí a imagem do eterno feminino que muito bem pode simbolizar a poesia. Então, poderíamos ver os mosquitos como a poesia moderna e sua disposição em penetrar o véu que protege e separa a virgem/poesia de tradição clássica do reino deste mundo. $\mathrm{O}$ elevado continua descendo e se familiarizando, em evidência de que as distâncias e as contradições se encurtam, se aproximam. A lua desce e os anjos passeiam pela terra: “Anjos da guarda em expedição noturna”. Os guardiões da moral e dos bons costumes, na tentativa de perpetuar a ordem vigente impõem as regras, fecham o cerco, para conduzir a virgem/poesia dentro da reta via.

Mas eis que no meio do caminho desse mundo ordeiro surge uma escada em espiral, por onde as virgens fogem, por onde a linguagem escapa. Instaura-se, assim, uma transitividade entre duas forças, entre duas instâncias, reforçada pela imagem espiral da escada: anjos descem à terra, virgens sobem ao céu. A espiral representa "a relação entre a unidade e a multiplicidade" e encerra, também, a "tentativa de conciliar a roda das transformações" (CIRLOT 1984: 241), haja vista que ela retorna ao mesmo ponto, mas num nível mais alto. Podemos relacionar essa imagem à idéia de movimento que marca a intelectualidade daquela época, expressando a insatisfação com a poesia ocupando sempre a mesma posição, perpetuando a pasmaceira de uma estética sem novidade, vazia das tensões que caracterizam o ser humano. $\mathrm{O}$ momento é de intensidade, de cumplicidade da poesia, como explica Drummond: 
Meu verso é minha consolação.

Meu verso é minha cachaça.

Para louvar a Deus como para aliviar o peito,

queixar o desprezo da morena, cantar minha vida e trabalhos

é que faço meu verso. E meu verso me agrada

Meu verso me agrada sempre... (1992: 33)

O ponto confluente desta escada espiralada é a poesia, mas uma poesia cheia de voltas, em movimento, agregadora de todos os sentimentos e atividades humanos, uma poesia liberta do que não é libertação. A espiral, em seu movimento ascendente, ao mesmo tempo em que recupera os mesmos elementos, coloca-os num nível mais alto. Assim, as virgens rompem o cerco e "tresmalham" por esta escada. Toda fuga é um desejo de libertação, é desejo de transformar pela própria experiência. As virgens transviadas não são lançadas para baixo, para a condenação, mas "incorporadas à vialáctea”, e por lá ficam “vaga-lumeando...”. Estaria o poeta deslocando as virgens bilaqueanas, ainda que sensuais mas muito puras, para uma outra Via-láctea? Nesta vialáctea modernista, as virgens não cintilam estaticamente, mas, por ter a liberdade de vagar pela amplidão sem fim é que melhor espalham seu brilho, um brilho descontínuo (o vaga-lume acende e apaga), do homem moderno fragmentado. $\mathrm{O}$ conceito de movimento que se estabelece desde a primeira estrofe, e que já se anuncia explicitamente no título, vai-se revelando nos versos para além da temática da comunhão entre os opostos, quando paramos para observar a primeira expressão do verso "diz-que tem virgens tresmalhadas,". O prosaísmo, a espirituosidade e a graça do boato (para não dizer fofoca) da expressão "diz-que" evoca a ironia e o humor habituais da subjetividade de Drummond, que por sua vez se revelam eficientes armas de combate no campo das artes, conforme afirma Bosi: "o humor cortaria, no estado atual das artes, toda ligação com as formas e os significados vigentes. (...) Há um momento em que o poeta mostra não tomar a sério os valores de uma certa cultura, ou melhor, as relações entre forma e conteúdo que a dominam: é a hora da paródia” (1977: 164-5).

O poeta recusa a linguagem e o comportamento correntes ao inserir a fala do cotidiano e sugerir a insubmissão comportamental. Parodiar as convenções vigentes é a forma de pensar valores mais próximos às exigências contemporâneas, o que significa que o poeta tem uma consciência crítica de seu tempo e de sua arte, pois a intenção de seu olhar não é destrutiva, mas construtiva, talvez tenha, como o teve William Blake, a 
intenção de edificar uma Nova Jerusalém, "cidade mística sem pecado nem lei; cidade onde os opostos se perseguem e se conciliam... cidade onde se festeja o casamento do céu com o inferno.”, resume Bosi (1977: 162).

Os versos seguintes, da quarta estrofe, flagram o diabo espiando a terra com seu olho torto. Parece ser o mesmo "anjo torto/desses que vivem na sombra" que apareceu ao poeta por ocasião de seu nascimento. O que o diabo espreita? O que ele cobiça? Está o diabo querendo estabelecer a desordem, a transgressão, ser, enfim, o porta-voz do mal, fazendo jus à tradição judaico-cristã? Mas, se aqui se vive o paraíso, por que as virgens estão transviadas, antes mesmo da intervenção demoníaca? Então, não se pode falar de ausência de conflito nesse paraíso terreal; o diabo não quer estabelecer a desordem, mas participar dela, tornar as coisas mais energéticas, considerando que o mal é a fonte de energia, a fonte de toda liberdade criadora. Segundo Willian Blake, em seu poema "O matrimônio do céu e do inferno", "Bem é o passivo que obedece à razão. Mal, o ativo emanando energia / Bem é Céu. Mal, inferno.” O que leva o bardo inglês à conclusão de que o céu é o inferno, e o inferno, por ser a fonte da energia e da criatividade, por ser ativo e libertador, por desobedecer à razão, o verdadeiro céu. Neste sentido, é o olho torto do diabo drummondiano que enxerga longe, porque tem lente de aumento, capaz de vasculhar "léguas de sete léguas". É um olhar penetrante porque sem censura, corruptível porque quer romper com o estado de coisas. É a atitude de Drummond e de seus colegas naqueles idos de 20 , de olho nos costumes burgueses, na linguagem das ruas e na poesia que estava distante da efervescência cotidiana; poesia cuja ausência de agudeza não esquadrinhava as contradições do dia-a-dia. A poesia de Drummond é a que vê longe e a que ouve bem, pois o diabo "tem o ouvido fino / que nem violino.", seu ouvido é de uma agudeza tão grande que repercute na rima e na acentuação. Esta rima já é o espírito livre e traquina do diabo inserindo a liberdade, a energia, a criatividade, o humor catártico, assim como o fogo dado aos homens por Prometeu, que acendeu a criatividade dos homens. A apatia na terra e a disposição em experimentar novas situações é ressonânica da indolência reinante no céu: "São Pedro dorme / e o relógio do céu ronca mecânico.”, enquanto o diabo continua de olho na terra. Há uma situação que favorece a inserção do elemento transgressor: a censura fecha os olhos, pouco se interessa pela sorte das coisas que controla. O mesmo não acontece com o paraíso recriado por John Milton: sabendo das conspirações de Satã, Deus manda que o anjo 
Rafael, por meio do sonho, previna Eva da ameaça de corrupção. Após a queda, os anjos julgam-se culpados por terem permitido que Satã rompesse o cerco: "As angélicas guardas pressurosas/Silenciosas e tristes se mostravam", mas a vigilância "foi justificada mui de pronto.” (MILTON 1970: 286). Em Drummond, parece que a vontade de Deus é que o homem caia em errância, a vontade é que a poesia, liberta da razão, do meticuloso e do convencional, instaure uma nova ordem. No Paraíso perdido, é Satã quem leva o conhecimento, a imaginação e a sensualidade ao homem. Após comerem do fruto, Adão e Eva "em alegrias nadam": "já imaginam que ... asas lhes cria / Com as quais voem desprezando a terra." Contudo, a primeira evidência do fruto libertador da transgressão é o despertar da luxúria, da lascívia: "E o carnal apetite lhes inflama./Sobre Eva lança Adão sôfregos olhos, / Ela com outros tais the corresponde; / No fogo da lascívia ambos se abrasam," (MILTON 1970: 277). A descrição do sexo libertador que foi possível pela ação satânica, em Milton, leva Blake a reconhecer no bardo inglês "um poeta autêntico", que "tinha parte com o Demônio, sem sabê-lo" (1987: 14). O diabo do olho torto, de tanto espreitar a terra, vislumbra aqui embaixo homens que também se esqueceram de Deus, pois de suas bocas machucadas não se ouvem mais rezas, e sim confissões de amor. É a santificação do prazer sexual, o culto do amor, a transformação do profano em sagrado. O corpo, tradicionalmente impuro, ocupa o lugar da alma. A sensualidade, que está ligada à sensorialidade humana, com seu poder energético e criador, livre da vigilância divina, eleva o homem ao infinito e o santifica, conforme afirma Blake: "Se as portas da percepção estivessem limpas, tudo se mostraria ao homem tal como é, infinito" (1987: 23). Segundo Blake, a maior virtude é quebrar regras, porque "Jesus era todo virtude, e agia por impulso, não por regras" (1987: 32). Unir os contrários: a razão e a energia, reconciliar a carne com o espírito, porque as tensões geram progresso e, em síntese, "Oposição é verdadeira Amizade" (1987: 29). Mas Drummond não se mostra preocupado com o espírito. É um momento em que o "baixo", o terreno, a materialidade significam mais. Portanto, a carne deve reconciliar-se consigo mesma: "e a carne penetra na carne.” É o mal convertendo-se em bem pelo seu princípio ativo que emana energia. Os corpos enrolados, que "ficam mais enrolados ainda" representam bem a comoção modernista, aquela que deixa o sujeito "comovido como o diabo". O homem vive a sua condição humana, e a poesia revela essa experiência. Como a lua e o céu perderam sua aura elevada e espiritual e se 
agregaram ao prosaísmo da existência humana, o homem também se revela em seus aspectos mais tendenciosos. Esta postura de valorizar a matéria, muito antecedente ao Modernismo, tem uma tradição que se perde no tempo, ainda que românticos mais ousados fizessem dela um grande achado, como é o caso, entre nós, de Álvares de Azevedo. Em seu "Prefácio" à segunda parte da Lira dos vinte anos, o poeta diz:

Há uma crise nos séculos como nos homens. É quando a poesia cegou deslumbrada de fitar-se no misticismo e caiu do céu sentindo exaustas as suas asas de oiro. O poeta acorda na terra. Demais, o poeta é homem (...) Tem nervos, tem fibra e tem artérias - isto é, antes e depois de ser um ente idealista, é um ente que tem corpo. E, digam o que quiserem, sem esses elementos, que sou o primeiro a reconhecer muito prosaicos, não há poesia. (AZEVEDO, 39)

De fato, nesta segunda parte de sua obra o poeta elege a lavadeira como musa, não larga o charuto, amaldiçoa o editor, a escassez de dinheiro e compara-se a uma lagartixa, dentre outras provas de que está acordado "na terra" e fazendo uma poesia que revele isso. No poema “É ela! É ela! É ela! É ela!”, o poeta mostra na lavadeira, por quem está apaixonado, a mulher real, demasiadamente vulgar, no lugar das musas idealizadas, porque é essa mulher palpável que realmente existe: “É ela! É ela! meu amor, minh `alma, / A Laura, a Beatriz que o céu revela..." Humor, ironia e sátira caracterizam essa poesia de reflexão que o coloca em sintonia com a modernidade, ao mesmo tempo em que faz dele um interlocutor de seu tempo. Drummond fecha a questão do "casamento do céu e do inferno" com versos humorísticos e reflexivos que caracterizam sua poesia, como postula Arrigucci Jr. em Coração partido, características sempre acompanhadas da "ambigüidade de tom decisiva na modulação dos temas de que tratam." (2002: 28) Com a contundente afirmativa "Que a vontade de Deus se cumpra!", verso que tanto pode referir-se à aceitação da sensualidade libertadora dos acontecimentos precedentes (virgens transviadas que vaga-lumeam, a concupiscência dos corpos enrolados) quanto à condenação irremediável desta mesma lascívia nos versos seguintes ("Tirante Laura e talvez Beatriz, / o resto vai para o inferno"), Drummond escapa pela estreita e sutil frincha da ambigüidade que coloca no inferno muito mais a idéia de um paraíso terreal. Segundo Álvares de Azevedo, poeta que desliza sempre para a modernidade, não se pode chamar de inferno um lugar em que há 
mulheres: "No inferno estão suavíssimas belezas, / Cleópatras, Helenas, Eleonoras; / Lá se namora em boa companhia, / Não pode haver inferno com Senhoras!" Se Álvares de Azevedo elenca as graças que serão encontradas no inferno, Drummond aponta as únicas que não estarão lá: “Laura e talvez Beatriz”. Representações máximas da beleza idealizada e espiritualizada, essas mulheres estabeleceram a tradição do eterno feminino ligado à pureza e à castidade, o que, a princípio, não levaria a distinções relevantes no que concerne à reputação ilibada de ambas, a ponto de o poetagauche colocar em dúvida a beatitude de Beatriz. O "talvez" seria apenas mais uma pitada de humor para acentuar a ambigüidade do verso antecedente e colocar mais uma pedra na "reta via" do leitor. O artigo de Livio Panizza (UERJ), "Beatriz e Laura em confronto", ainda que não desfaça o desconforto desse julgamento por demais severo com Beatriz (ela é e sempre será a manifestação da graça divina), esclarece que antes de atingir o amor sublimado, Beatriz inspirou o amor carnal:

Do amor carnal, da paixão presente no início da Vita Nuova eleva-se a expressões de amor mais elaboradas, próprias da "charitas", reforçadas pelas experiências intelectuais do Convívio até chegar a formas espiritualizadas e sublimadas na Divina Comédia. Dante, no início da Vita Nuova amou Beatriz segundo os cânones do amor cortês, cantando a beleza do seu olhar, a beleza de sua face, a graça e a modéstia de seus gestos. Nesse primeiro encontro Dante é presa de turbações e de angústias que invadem até seus sonhos, mas ao término da obra seus sentimentos são sublimados.

Quanto a Laura, ela nunca foi uma mulher real, mas um modelo de beleza, “ o modelo do qual o pintor se apaixona, não como homem, mas como pintor, preocupado muito mais em representá-la do que possuí-la”, conclui Panizza.

Ao final da leitura do poema, somos obrigados a repensar seu título e, para entendê-lo, reavaliar as ações da santíssima trindade que sustenta o texto: o homem, o diabo e Deus (representado por São Pedro). Vimos que São Pedro dorme, o diabo olha e o homem faz. As virgens se desgarram por conta própria, os homens trocam as profissões de fé pelas confissões de amor e vivem deliciosamente a sua luxúria, sem precisar que o diabo a propicie. Assim, o diabo perde seu posto, para o homem, de príncipe do desregramento e torna-se apenas espectador atento, desejoso de participar 
das ações humanas, porque nelas se reconhece. A ação diabólica é atenuada (o diabo está em cima e apenas vê) e o caráter demoníaco do homem é acentuado. Se no Paraíso perdidoSatã é a personagem principal e o homem a vítima de suas artimanhas, neste casamento drummondiano o homem é o portador do conhecimento que liberta, da energia criadora, por isso "a carne penetra na carne". Desta forma, não temos a reconciliação da carne com o espírito proposta por William Blake, e o poema de Drummond torna-se uma paródia ao "O matrimônio do céu e do inferno", quando a junção das tensões ainda precisava ser reclamada. O homem contemporâneo de Drummond já incorporou o espírito demoníaco, o que leva sua poesia a transitar entre dois mundos: o do combate, por estar dentro de uma tradição de ruptura, e o da paródia, porque seu olho torto vasculha além de seu tempo.

\section{OBRAS CITADAS}

ANDRADE, Carlos Drummond de. 1992. Poesia e prosa. Rio de Janeiro: Nova Aguilar.

ARRIGUCCI JR., Davi. 2002. Coração partido. Uma análise da poesia reflexiva de Drummond. São Paulo: Cosac \& Naify.

AZEVEDO, Álvares de. 1996. Poesias completas. Rio de Janeiro: Ediouro.

BLAKE, William. 1987. O matrimônio do céu e do inferno. Trad. José Antônio Arantes. São Paulo: Iluminuras.

BOSI, Alfredo. 1977. O ser e o tempo da poesia. São Paulo: Cultrix.

MILTON, John. 1970. Paraíso perdido. Trad. António José Lima Leitão. São Paulo: W. M. Jackson.

PANIZZA, Livio. 2004. "Beatriz e Laura em confronto". Cadernos do CNLF. Disponível emhttp://www.filologia.org.br/viiicnlf/anais/caderno04-06.html. Acesso em maio de 2006. 


\title{
A musicalidade flamenca de João Cabral
}

\author{
Everton Barbosa Correia (UNICAMP)
}

RESUMO: Dado que poesia de João Cabral de Melo Neto se constituiu como uma das mais significativas da literatura brasileira, interessa distinguir no contexto da modernidade como a dialética do localismo versus cosmopolitismo se processa naquela obra, produzida em larga medida na Espanha e cuja tematização comporta simultaneamente elementos de nacionalidade e de universalismo. Daí cumpre investigar como se manifesta tal contradição, considerando a musicalidade dos poemas que tematizam o flamenco - expressão da Andaluzia -, coligidos no livro Museu de tudo. A partir do diálogo que os poemas estabelecem entre si, espero chegar numa compreensão particular da obra, já que a rítmica ali em curso traz elementos da cultura popular hispânica que servem aos princípios de composição do poeta brasileiro.

PALAVRAS-CHAVE: Poesia brasileira moderna; João Cabral de Melo Neto; Cosmopolitismo; Musicalidade flamenca.

\begin{abstract}
It would be interesting to distinguish João Cabral de Melo Neto's work in context of modernity, since it was constituted like one of the most significant of Brazilian literature. It means to analyze how localism versus cosmopolitism dialectic is processed in that work, produced largely in Spain, whose subject matter include simultaneous facts of nationality and universalism. Because of that, it has to be investigated how such contradiction express itself, considering the musicianship of poems collected in Museu de tudo deal with flamenco - Andaluzia's expression. I hope to find a particular comprehension of work, from the dialog that poems establish to each other, due to rhythm current there to bring elements of popular Spanish culture, that serve to Brazilian Poet's compositions principles.
\end{abstract}

KEYWORDS: Modern Brazilian poetry; João Cabral de Melo Neto; Cosmopolitism; Flamenco musicianship.

Para alguém que passou toda uma vida a renegar os princípios melódicos que animam o fazer poético, é no mínimo controvertido tematizar uma forma musical, tal como acontece com João Cabral de Melo Neto quando versa sobre o flamenco. Mais estranho seria se ele escolhesse uma outra forma musical, já que apenas o frevo e o maracatu aparecem episodicamente na sua obra como remissões à música brasileira. Em relação à música estrangeira, sua indiferença não é menor, mas se revela de outra maneira quando nos voltamos para a música vinda da Andaluzia. 
Também é verdade que a tradição literária que se constitui a partir do romantismo desenvolve um certo gosto pela musicalidade inerente à feitura dos versos, o que, sob certa ótica, se radicaliza na produção dos autores de língua portuguesa e que o poeta pernambucano evita a todo custo. Assim, ao mesmo tempo em que o poeta se esquiva de uma certa tradição - afeita à música -, reivindica para si uma filiação noutra tradição - afim à plástica -, e mais próxima da poesia espanhola. De modo que, ao falar doflamenco, não é só uma expressão musical que está sendo acionada, mas também uma tradição popular que conjuga, a um só tempo, elementos visuais e verbais à expressão musical. Daí resulta uma modalidade de texto que se faz, simultanemente, em diálogo com a música e com a dança.

Além disso, João Cabral sempre esteve às voltas com expressões populares, o que pode ser percebido no plano formal pela sua simpatia às redondilhas e tematicamante na produção que encerra o Tríptico do Capibaribe, para ficarmos em poucos exemplos. Todas essas considerações ganham uma outra dimensão quando pensadas em função de uma expressão popular espanhola, que, sendo simpática ao autor, é estrangeira. Assim, o poeta recoloca noutros moldes uma questão que já havia sido levantada, inicialmente, na época do romantismo brasileiro e que passa pela interseção entre o nacional e o cosmopolita. Acontece que, pelo próprio ofício de diplomata, o poeta precisaria estar em contato com outras culturas. O que parece complicado é quando ele passa a assimilar parte dessa cultura para sedimentar uma expressão própria, das mais representativas na poesia brasileira.

Mais curioso ainda é o momento em que ele passa a tematizar sistematicamente o flamenco. Da sinuosa trajetória que a obra de João Cabral de Melo Neto segue, muito chama a atenção o livroMuseu de tudo, pela ordem de publicação - bem no meio do seu percurso cronológico -, e também por sua característica um tanto difusa, que, numa primeira leitura, foge aos princípios preconizados pelo autor. Ou ainda, pelo próprio poema de abertura, que sugere um balanço da obra e dá título ao livro.

O equilíbrio e a objetividade que marcam tão pontualmente a obra de João Cabral parecem adquirir outros contornos a partir daí, quando vai se percebendo uma abertura daquele rigor tão imperativo que distinguia sua obra em todas as suas dimensões. Neste caso, se há um estilo que atravessa o livro, podemos percebê-lo mais 
claramente no interior de cada poema, mas isso não vai acontecer igualmente na sua estruturação.

Este livro ocupa, pois, um lugar todo especial na obra do autor, uma vez que amplia sua identidade poética e recupera, ao mesmo tempo, alguns dos elementos que lhe são distintivos. Por isso, o livro resguarda alguns procedimentos que ficaram reconhecidos como próprios da obra cabralina, mas sem se restringir a eles, tais como: aproximação entre a cultura brasileira e a espanhola; uma exploração social cujo correspondente na linguagem se faz imperativo, como podemos ver no poema:

El cante hondo

This is the way the world ends Not with a bang but a whimper T.S. Eliot

$\mathrm{O}$ cante hondo às mais das vezes desconhece essa distinção: o seu lamento mais gemido acaba em explosão.

Tão retesada é sua tensão, tão carne viva seu estoque, que ao desembainhar-se em canto rompe a bainha e explode.

Uma informação válida sobre o poema é que sua realização se ocupa em converter um objeto de representação em outro, uma vez que "O cante hondo" já é, por si mesmo, um objeto de representação que recupera a cultura popular mais remota. Através da mistura entre ciganos e outras gentes vividas na Andaluzia, o canto traduz noutra esfera um tipo de representação que remete de pronto à situação existencial de um povo, cujos meios de expressão the caracterizam, sobretudo, porque o que está sendo sufocado apresenta esse povo em estado de dilatação máxima, que é próprio do canto e passa a ser também de quem se reconhece nele.

Se o título do poema serve, por um lado, para marcar a posição do poeta em relação ao país estrangeiro de sua maior predileção, por outro, estabelece um diálogo entre o título e o texto que se segue. De modo que o estranhamento suscitado de início tem uma duração no poema que o constitui integralmente, do título ao último verso. Ou 
seja, se a explosão anunciada já na epígrafe provoca um estado de suspensão, o poema retém sua tensão até explodir, tomando, portanto, o caminho inverso ao enunciado.

Nesse poema de João Cabral, quando aparece a palavra "explosão" provoca-se uma rima forçada com "distinção", rompendo a mesura dos demais versos. O verso distinto na primeira estrofe é, portanto, aquele que explode internamente no poema. A rima entre "distinção" e "explosão" reverbera na palavra "tensão", criando uma cadeia significativa que serve de mote para os demais versos. A pobreza da rima entre o segundo e o quarto verso da primeira estrofe vai ser coberta pela rima toante entre o segundo e o quarto da segunda estrofe, como se houvesse noutro plano o mesmo movimento da explosão contida. Por outra, o estoque carnal do canto é que o explode.

A apreciação da musicalidade na obra cabralina, tão controvertida neste poema quanto em qualquer outro, aqui merece uma atenção especial. Pois, se as rimas toantes e os octossílabos dificultam a cursividade dos versos, sua sonoridade fica ainda mais intricada pelo uso quase excessivo das oclusivas. Ao que as sibilantes respondem em sentido inverso, reproduzindo noutra esfera a contradição expressa anteriormente, que poderíamos resumir como caracterizada entre dois pólos, o da dilatação e o da contenção. Na primeira estrofe há uma predominância das sibilantes, mais evidenciada no dístico: "O cante hondo às mais das vezes, desconhece essa distinção", até que o poema explode no quarto verso, como se houvesse um sussurro que prepara, na verdade, a explosão contida de que se constitui o poema. A partir daí, há um maior equilíbrio entre essas duas bases sonoras, em que o ribombar das oclusivas recebe como indumentária as sibilantes, que atenuam o seu barulho e lhes dão um som quase melódico. Uma interpretação possível para isso seria a de que essa ambivalência mimetizasse a explosão contida de que o poema se constitui em sua própria expressão.

Gostaria ainda de lembrar de dois outros poemas que enfeixam o Museu de tudo e dialogam diretamente com "El cante Hondo", para que, assim, cheguemos a uma adjetivação mais precisa desse canto e tenhamos fios mais amplos da tessitura que o poeta engenha, seguindo a ordem de publicação no livro:

Ainda el cante flamenco

É a música desejada

como o que não adormece: 
o mais contrário do embalo

e do canto emoliente.

$\mathrm{Na}$ Andaluzia esse canto

insonífero se atende:

a contrapelo, esfolado,

arrepiando a alma e o dente.

Salvo o primeiro dístico em que se mantém a tensão já anunciada, aqui o autor parece ter buscado uma expressão bem mais espontânea, sob uma tonalidade bem menos rígida do que a do poema anteriormente analisado, inclusive pela disposição dos versos numa única estrofe. Outra oposição formal importante é a de que os versos daquele poema são em sua maioria octossílabos, apenas o quarto verso tem seis sílabas; já aqui o metro utilizado é o redondilho, o que também contribui para a impressão de um ritmo mais solto em cada um dos versos, que reverbera no poema como um todo.

Se esta é a primeira impressão que se depreende das informações técnicas mais visíveis, ao longo do poema uma outra compreensão vai se configurando em compasso com o enunciado referencialmente expresso. Nesta linha de raciocínio, o quarto verso traz uma palavra que se destaca das demais pelo inusitado em meio a um vocabulário excessivamente simples, dado pelas outras palavras. "Emoliente" chama ainda mais a atenção pelo tom distenso, quando no nível semântico o enunciado aponta para outro lado. Como se a expressão pretendida no poema repousasse sobre uma suposta contradição, a de uma melodia maleável que encobre um sentido duro. De alguma maneira podemos entrever esta contradição formal como uma tradução doflamenco noutro nível que, sugerindo um lamento choroso, não apazigua e nem conforta o sujeito, mas, ao invés disso, acende-o, o arrepia, deixa-o por inteiro ligado em vez de embalado ou adormecido.

Trata-se, portanto, de um canto para manter-se acordado, que se ouve pelo avesso, todo aberto, abrindo o que há de mais interno, a alma, e também sua expressão mais exterior, o dente, não em sorriso, mas expandindo o canto no que ele tem de esfolado, a contrapelo, embora assim não se pareça à primeira vista. Noutras palavras, $o$ poeta se empenha em demonstrar como o canteflamenco pode ser visto por diversas camadas, em cada um dos poemas abordados, o que análise em curso tenta reproduzir, acompanhando a exploração mais minuciosamente formal do som incrustado na poesia até sua configuração lexical e semântica. Assim, teríamos alguns aspectos do mesmo 
canto, observados por vários ângulos. Nessa medida, cumpre também pontuar que gradativamente o autor vai passando de uma exploração mais material do canto, tal como vimos até aqui, para uma escritura de feição mais abstrata - já que passa por filtros muito próprios à sua poesia -, levando-nos a outra compreensão do flamenco e da sua musicalidade, que se estende a da poesia cabralina, tal como apresenta o poema que se segue.

Habitar o flamenco

Como se habita uma cidade se pode habitar o flamenco: com sua linguagem, seus nativos, seus bairros, sua moral, seu tempo.

\begin{abstract}
A linguagem: um falar com coisas
e jamais do oito mas do oitenta;

seus nativos: toda uma gente

que existe espigada e morena;

seus bairros: todos os sotaques

em que divide seus acentos;

sua moral: a vida que se abre

e se esgota num instante intenso;

seu tempo: borracha que estica

em segundos de passar lento,

lento de sesta, sesta insone

em que se está aceso e extremo.
\end{abstract}

Este poema se efetiva por reproduzir o flamenco em suas múltiplas dimensões e não exclusivamente como canto -, uma vez que se faz em função de sua linguagem, seus nativos, bairros, moral e tempo. Trata-se, portanto, de uma expressão muito bem demarcada nas suas inúmeras variantes. Por outro lado, considerando o poema como uma expressão própria de João Cabral, que revela algo de sua musicalidade intrínseca, a qual pode ser habitada, parece-nos uma realização um tanto enigmática. Pois, ainda que tomemos uma definição muito ampla de música, a saber, uma sucessão de sons arranjados que decorre no tempo, mesmo assim teríamos considerável dificuldade em precisar o flamenco de João Cabral, que se materializa num espaço a ser habitado com linguagem, nativos, bairros, moral e tempo próprios. O seu tempo pode ser esticado, porque está materializado na borracha, que, tensionada, acende sua duração ao extremo, intensificando-a; a moral posta em movimento requer a mesma intensidade da vida que se abre e se esgota num instante; sua gente morena adquire um porte espigado que não 
deixa de revelar uma nobreza chã; e sua linguagem encontra-se já em estado de dilatação máxima.

Aqui se consolida o império do quatro: quatro quadras que se distribuem em dezesseis versos de oito sílabas. Acontece que nas duas estrofes nucleares, quais sejam, a segunda e a terceira, vamos encontrar a descrição simétrica de quatro dos elementos com que se constrói o seuflamenco: a cada elemento, dois versos. Ao passo que a primeira e a última estrofes tomam outra feição: a primeira, apresenta o flamenco com cinco elementos e como espaço habitável, qual uma cidade; já a última estrofe é dedicada exclusivamente ao tempo, que se materializa em borracha e não concede sono ao sujeito, porque estica o tempo da vivência, que reclama intensidade.

O curioso do enunciado é que a linguagem doflamenco, tal como foi apresentada, constitui-se por um falar com coisas do oitenta, em oposição às coisas do oito. Só não podemos esquecer que o verso é a instância material, onde melhor podemos inscrever a dicção do poeta, que, neste caso, é tomado deliberadamente como coisa estruturada em octossílabo. Noutras palavras, é como se o poeta estivesse dizendo: eu admiro e pretendo as coisas do oitenta, mas só consigo as do oito. Ou ainda, eu só vislumbro as coisas do oitenta como possibilidade em potencial, mas não como efetividade discursiva. Tratando-se de quem é o poeta, uma declaração dessas tanto pode tomar um ar irônico, quanto fatalista, se considerarmos como saldo a tradição da literatura brasileira e os descaminhos ainda não explorados de todo pela língua portuguesa.

A medida do flamenco seria, nesta proporção, o espaço almejado e até vivenciado por sua civil geometria, mas ainda não consolidado de fato, mas já apontado como limite a ser encarado. Ainda mais se voltarmos àquela compreensão desenvolvida a propósito da leitura do poema anterior em que, sob a casca formal do flamenco, encontramos uma informação preciosa para sua compreensão. Sendo esta, por si mesma, contraditória, mas que não deixa de reclamar uma certa postura de seu ouvinte, porque já configurada pelo seu cantante.

De um modo ou de outro, o poeta faz coincidir uma moralidade e seu correspondente na linguagem, não só como resultado de uma busca no poema, mas 
como tentativa de atingir, na própria expressão, a mesma especulação que o conduziu a determinados princípios. Portanto, nem a moralidade nem a linguagem que a apresenta são frutos de reinvindicações anteriores à construção da obra e tampouco uma é feita em detrimento ou à revelia da outra. Ao contrário, ambas vão se constituindo na medida em que a obra se faz, até que a linguagem adquira uma ressonância semelhante à da moral expressa, para poder assegurar a legitimidade do princípio e seu estatuto literário. Para tanto, é preciso conceber as duas dimensões emaranhadas uma na outra, para podermos averiguar, afinal, que moralidade é essa que o poeta requer para a linguagem de sua poesia, que se constitui como ética mais do que como moral, já que não cessa de pensar a si mesma a todo o instante em toda a sua duração.

Neste sentido, se a matéria é o cante flamenco, habitável e explosivo, redondilho e enquadrado, aponta mais para quem fala do que para aquilo de que se fala. As suas mesmas palavras continuam girando em torno do que é quatro, como se esse princípio valesse por si mesmo enquanto símbolo de racionalidade, que sua poesia encarna. Não é de estranhar, pois, o caráter efusivo que ele devota à cultura espanhola e, em especial à poesia dali surgida, já que através desses índices ele pode alimentar sua fixação na limpidez e dureza de seu raciocínio, que parecem melhor saciados quando convertidos em algo que se aproxime do quatro. Esta escala, sempre a postos, conduz o poeta para um lugar todo próprio, que já não é só o Recife de sua memória e nem o país estrangeiro que melhor o acolheu, mas alhures aproxima-o de uma condição bem própria do homem contemporâneo, que ainda parece ter alguma graça quando refletido nas suas palavras, porque ainda parece ser capaz de se assenhorar do universo à sua volta, enquadrando-o.

A sua realização é, portanto, algo que passa pelo filtro da racionalidade, mas não se restringe a ela como parte de uma tradição. Mas, sem desconsiderar este lado, explora-o com todas as forças como se fosse uma novidade, em que o rústico e o prosaico encontram o mesmo terreno, como se a novidade residisse no fato de astuciosamente abolir a tradição poética composta em paralelo à racionalidade, para pontencializar a ambas, aquela tradição e a racionalidade. O mais curioso é que os princípios que sustentaram a razão iluminista só precariamente parecem encontrar recurso na sua obra, senão quando transfigurados em procedimentos formais bem particulares que lhe servem de suporte. Nesta instância, já passaram a ser outra coisa nas 
palavras de João Cabral, quando cada referente adquire um novo sentido. E não podemos deixar de acreditar que esta seja uma atitude racional, só que sua racionalidade se pauta em testar todos os limites do seu próprio sujeito e, porque não, da própria racionalidade, agora convertida em discurso poético.

\section{OBRAS CITADAS}

ATAHYDE, Félix de. 1998. As idéias fixas de João Cabral de Melo Neto. Rio de Janeiro: Nova Fronteira: FBN; Mogi das Cruzes, SP: Universidade de Mogi das Cruzes.

BARBOSA, João Alexandre. 1975. A imitação da forma. São Paulo: Duas Cidades.

CARONE, Modesto. 1979. A poética do silêncio. São Paulo: Perspectiva.

CASTEllo, José. 1996. João Cabral de Melo Neto: o homem sem alma. Rio de Janeiro: Rocco.

ESCOREL, Lauro. 2001. A pedra e o rio. $2^{\mathrm{a}}$ ed. Rio de Janeiro: Academia Brasileira de Letras.

GARCIA, Othon Moacyr. 1996. Esfinge Clara e outros enigmas: ensaios estilísticos. $2^{\mathrm{a}}$ ed. Rio de Janeiro: Topbooks.

HOUAISS, Antônio. 1976. Drummond mais seis poetas e um problema. Rio de Janeiro: Imago.

HOLANDA, Sérgio Buarque de. 1978. Cobra de vidro. 2.ed. São Paulo: Perspectiva/ Secretaria da Cultura, Ciência e Tecnologia do Estado de São Paulo.

LIMA, Luiz Costa. 1995. Lira e antilira: Mário, Drummond, Cabral. $2^{\mathrm{a}}$ ed. Rio de Janeiro: Topbooks.

MELO NETO, João Cabral de. 1994. Obra completa. Organização: Marly de Oliveira. Rio de Janeiro: Nova Aguilar.

. 2001. Correspondência de Cabral com Bandeira e Drummond. Organização, apresentação e notas de Flora Sussekind. Rio de Janeiro: Nova Fronteira; Fundação Casa de Rui Barbosa.

MERQUIOR, José Guilherme. 1997. A astúcia da mímese. 2a ed. Rio de Janeiro: Topbooks.

NUNES, Benedito. 1971. João Cabral de Melo Neto. Petrópolis: Vozes. 
CORREIA, E. B. A musicalidade flamenca de João Cabral

SECCHIN, Antônio Carlos. 1999. João Cabral: a poesia do menos e outros ensaios cabralinos. $2^{\text {a }}$ ed. Rio de Janeiro: Topbooks.

STEEN, Edla van. 1981. Viver e escrever. Porto Alegre: L\&PM. 


\title{
O Ornitólogo e a Arapuca: Notas sobre a Palavra Cerzida e Grupo Escolar de Cacaso
}

\author{
Débora Racy Soares (UNICAMP)
}

RESUMO: Quando convocado a se definir como poeta, Cacaso (1944-1987) teria dito que era poeta que escuta. Tal atitude poética certamente resulta em um tipo de poesia aberta à experiência alheia. Até aí parece não haver muita novidade, pois a disponibilidade para ouvir combina bem com uma outra, a de "espírito", que Cacaso acreditava ser mesmo imprescindível à criação artística. Mas se ambas as disponibilidades podem se confundir, em determinado momento, uma nem sempre implica a outra. Em outras palavras: nem sempre quem ouve consente. E se quem cala, sente, Cacaso - apesar de, aparentemente, "não querer prosa" - apostava na força vital do diálogo para reavivar o monólogo oficial. Nossa proposta é escutar sua trajetória poética, dando ouvidos a um modo muito peculiar de fazer versos.

PALAVRAS-CHAVE: Cacaso; criação artística, experiência.

ABSTRACT: When summoned to define himself as poet, Cacaso (1944-1987) would have said that he was a poet who listened. Such poetical attitude certainly results in a type of a poetry open to the other people's experience. Until that, it seems there is nothing new, therefore the availability to hear combines well with one another, that of "spirit", which Cacaso exactly believed to be essential to the artistic creation. But if both availabilities can be confused, in a specific moment, one does not always imply to the other one. Or not always one who listens assents to it. And if that who is silent, feel, Cacaso - although, apparently, "not wanting to chat" - bet in the vital force of the dialogue to revive the official monologue. Our proposal is to listen to its poetical trajectory, listening to a very peculiar way of making verses.

KEYWORDS: Cacaso; artistic creation; experience.

\section{INTRODUÇÃO}

Antônio Carlos de Brito, mais conhecido por Cacaso no meio intelectual e literário dos anos setenta, além de crítico e teórico de sua geração - a dos "marginais do mimeógrafo" - também foi poeta. O fato merece atenção, já que suas poesias parecem 
ter, até então, passado despercebidas das lentes dos críticos literários. Salvo, é preciso dizer, raras e localizadas exceções que, apesar de mencioná-lo, não detêm o olhar na especificidade de seus versos. É interessante perceber que a produção poética de Cacaso tem, recentemente, despertado a atenção de alguns estudiosos, desejosos em ressuscitálo. Talvez não tenha sido caso de morte. Ou se foi, a "indesejada da gente" parece ter atingido somente a poesia. Isso porque se o poeta, morto de fato em 1987, precisa ser relembrado em matéria de poesia, no quesito música, não the faltam ouvidos. Sem muito esforço e, com um pouco de sorte, ainda é possível sintonizar "Lero-Lero" em algumas FMs do país. Com letra de Cacaso e música de Edu Lobo, com quem iniciou uma produtiva parceria em 1976, o hit que caiu no gosto do público seria posteriormente regravado por vários artistas, como os do grupo Garganta Profunda. Se a quadrinha "Sou brasileiro/de estatura mediana/ gosto muito de fulana/ mas sicrana é quem me quer" tornou-se familiar, não é preciso relembrar uma de suas principais composições, "Dentro de Mim Mora um Anjo", interpretada magistralmente, em 1975, por sua outra parceira: Sueli Costa. A música virou trilha sonora da novela "Bravo", da Rede Globo, tendo sido, posteriormente, incluída no repertório de Fafá de Belém. Para os que na época não tinham nascido ou usavam fraldas, é possível escutar "Dentro de mim...” em show recente de Lucinha Lins.

Diante destas observações, somos tentados a recorrer aos questionamentos de outro poeta, também mineiro, como Cacaso, porém de Itabira, não de Uberaba. Quem “entortou” nosso ouvido ou a poesia? A pergunta é pertinente, já que a produção do letrista e do poeta corria pari passu. Nesse sentido, desconfiamos de que, a partir de um determinado momento, o trânsito entre poesia e letra de música passou a ser intenso. Apesar de Cacaso acreditar que poesia e música eram dois "negócios" completamente distintos, no percurso de suas composições percebemos como muito do que ali se encontra, já havia se esboçado poeticamente. Versos inteiros descolam-se dos livros de poesia e são reaproveitados em forma de quadrinhas ou refrões musicais. Cacaso experimenta o som e o ritmo das palavras nas quebras e repetições de suas letras e poemas. A poesia parece, dessa forma, servir como celeiro para as letras de música. Talvez o inverso também seja pertinente, mas não importa muito entrar em discussões como as do "ovo-galinha". Vale mais perceber que Cacaco, em um primeiro momento, 
encarava as duas atividades de formas bem distintas e tinha expectativas diversas em relação a elas.

\section{O LETRISTA QUE ERA POETA}

No palpite de Helena Aragão, Cacaso parece ter ficado conhecido antes como poeta do que como letrista. Será? Vejamos. Seu primeiro livro de versos, A Palavra Cerzida, é de 1967. Mas por onde andava Cacaso antes de sua aparição no cenário literário brasileiro? Em 1962, com 18 anos, Cacaso acabara de compor "Carro de Boi” com Maurício Tapajós. Com esta música, gravada pelo grupo "Cariocas", ele demarcaria seu lugar no terreno musical da época. A canção ficou tão popular entre o pessoal do "Clube da Esquina" que Milton Nascimento resolveu regravá-la em seu disco "Geraes", de 1976. É nesse período que sua atividade musical deslancha, ao lado de parceiros como Nelson Ângelo e Novelli. Daí para frente, a produção musical de Cacaso se intensifica, enquanto sua produção poética decresce. Ou como ele diz, em 1980: "tem uns dois anos que eu não consigo fazer um poema, a verdade é essa. Só sei fazer letra de música" (1981: 08). Não sem certa tristeza, Cacaso reconhece que, desde seu livro de 1978 - Na Corda Bamba - sua poesia "foi ficando pequena, foi diminuindo o tamanho, e sumiu" (1981: 08). Seu próximo livro, Mar de Mineiro que sairia em 1982, é um livro de poemas e canções. Mais canções (75) do que poemas (44). Dedicado aos parceiros musicais Nelson Ângelo e Novelli, Mar de Mineiro baliza a definitiva passagem de Cacaso da marginalidade poética (esgotada em sua essência com as sinalizações de abertura política) e a sua consagração no mercado fonográfico. É a partir de 1976, como lembra Nelson Ângelo, que Cacaso começa a intensificar sua produção musical. Sua idéia era "compor bastante" para quando "as pessoas perceberem", já “estar com um projeto pronto" (2000: 110). Aliás, é com Nelson que Cacaso compõe mais de oitenta canções, muitas das quais escritas quando se encontravam para produzir. Era na casa de Cacaso que, aos goles de pinga mineira, os parceiros admiravam o mar de Copacabana e lamentavam a inexistência de mar em Minas. Dois mineiros (Nelson nasceu em Belo Horizonte), convertidos à maresia, sofriam de um mal maior: saudades Gerais. Em 2002, Nelson Ângelo lançou o CD Mar de Mineiro, com 13 músicas oriundas de sua parceria com Cacaso. No encarte que acompanha o $\mathrm{CD}$, Nelson recorda quanto ambos acalentavam, desde os anos setenta, o sonho de gravarem juntos. 
Segundo Cacaso, a música poderia lhe garantir projeção nacional e com ela teria "chance de ficar conhecido no Brasil inteiro". No que tange à poesia, Cacaso acreditava que mesmo que ela desse certo, poderia deixá-lo "confinado ali na esquina". E acrescenta que sua "experiência com poesia" era "num setor minúsculo" (2000: 109). À medida que Cacaso foi percebendo sua musicalidade e sua capacidade de "inventar palavras sobre melodias”, passou a não mais dissociar música e poesia (2000: 113). Sua mudança de opinião provavelmente foi condicionada por seus estudos em "música, modernismo, cultura brasileira" (2000: 104). A leitura de Mário de Andrade parece ter sido fundamental neste momento. Além de ter influenciado Cacaso em sua busca de sonoridades, parece ter-lhe assegurado também o "direito à pesquisa" e "à liberdade de inovar", como condições determinantes de sua atividade criativa (2000: 107). Para ele, após Vinícius de Moraes, a música e a poesia brasileira estariam "misturadas para sempre" (2000: 109). Aliás, Cacaso chegou até mesmo a ser considerado o "legítimo herdeiro" do "poetinha" quando começou a fazer sucesso no meio musical (Hollanda 2000: 240).

Durante a infância, uma das "brincadeiras prediletas" de Cacaso era colocar "mentalmente uma letra nova nas melodias que ouvia no rádio". Foi através da música, diz ele, que aconteceu seu "primeiro contato com o texto" (2002: 109). Aliás, quando era pequeno, cantor de rádio era o que almejava ser no futuro. O "poeta que escuta", como Cacaso se autodenominava, era desafinado. "Cantava fora do tom o verso que acabara de compor" (Landim, 2000: 113). E era entendido em passarinhos.... Ainda está por ser feito um trabalho que se dedique exclusivamente às letras de música de Cacaso.

\section{O POETA QUE ERA LETRISTA}

A estréia poética de Cacaso, em 1967, com A Palavra Cerzida, embora tenha sido louvada pelo crítico José Guilherme Merquior, em nota introdutória do livro, revelou-se uma "experiência muito frustrante" para o autor. Cacaso que, naquela ocasião, assinava Antônio Carlos de Brito, diz ter ficado "sete anos sem conseguir escrever" após a publicação deste primeiro livro (1981: 06). Esse livro que saiu sob o aval da editora José Álvaro, nunca foi, na opinião de Cacaso, "lido" ou "comprado por ninguém" (1981: 06). Como ele foi "uma coisa tão inexistente na (sua) vida" e lhe 
causou a "sensação de ser editado, e não ser", Cacaso foi levado a desconfiar de suas possibilidades como poeta. Em sua opinião, a recepção quase nula de A Palavra Cerzida deveu-se ao fato de ter escrito "uma poesia muito complicada, muito intelectualizada, com pretensão um pouco filosófica" (1981: 06). Motivado pela pretensa baixa receptividade de sua obra, Cacaso procurava justificar sua "complicação" poética dizendo que na época era estudante de Filosofia (na UFRJ). Em outros momentos, chega até a afirmar que o livro de 1967 é "um livro de estudante de Filosofia" porque "tem o ser e o nada". "Mais construído" e "menos voltado para a vida" é como o jovem poeta considera seu livro inicial (Pereira1981: 164). Será com Grupo Escolar (1974), seu segundo livro, que Cacaso inaugurará sua fase "marginal do mimeógrafo". Neste novo momento de sua produção poética as motivações para escrever são outras e refletem a dicção mais espontânea - que não se dá sem grande esforço construtivo - e aparentemente menos literária do autor. Cacaso diz ter sido encorajado a "volt(ar) a arriscar" escrever poesia, estimulado por Ana Luísa Escorel (1974: s/p). Ele havia cooperado com sua tese para a Escola Superior de Desenho Industrial, escrevendo poemas para ilustrar determinadas imagens. Portanto, a maioria dos poemas de Grupo Escolar só ganha força se lida no diálogo com o suporte imagético. É lamentável que a recente edição da coletânea das obras poéticas de Cacaso (Lero-Lero, 7 Letras, Cosac \& Naify, 2002) tenha suprimido todas as fotos e desenhos dos livros originais. As fotos da edição original de Grupo Escolar são de Maria Elizabeth Ribeiro Carneiro, a Betinha (assim chamada pelo poeta), que ao lado de Ana Luísa, autora da capa, são consideradas "co-autoras" do livro (Brito, 1974: s/p).

Grupo Escolar é o primeiro livro de Cacaso produzido alternativamente. Ele integrou a Coleção Frenesi do Rio de Janeiro e, para ser publicado, contou com o apoio financeiro da Mapa Filmes Ltda., através de Zelito Viana. A idéia da publicação, de forma independente, através de Coleções de poesia, fez parte da dinâmica de produção dos poetas conhecidos como "marginais dos anos 70". Ao tomar as rédeas do movimento marginal carioca, sendo um de seus principais teóricos, Cacaso encarava a "liderança" como sua "atividade mais séria", junto com a de "letrista da MPB" (2000: 102). 
Neste momento, a poesia passou a ser encarada de forma diferente. Se antes, em A Palavra Cerzida, a produção poética exigia uma "programação rígida", de Grupo Escolar em diante, ela passa a acontecer "a todo tempo" e "em qualquer lugar" (Pereira 1981: 164). A volta à poesia, diz Cacaso, acontece por "razões que não têm nada a ver com a literatura, razões muito mais de desabafo pessoal e de vontade de juntar umas pessoas, fazer planos e editar coleções de livros” (1981: 06). É nesse momento que Cacaso tem a "sensação de ser um autor de livros de poesias" (1981: 07). A divulgação e distribuição dos livros de poesia, feitas manualmente e em locais restritos, contribuíram para que Cacaso fosse reconhecido como poeta, ainda que "num circuito minúsculo". Certamente o poeta queria ser reconhecido e é difícil avaliar se a "fama" que o "deixava um pouco atrapalhado" decorria de sua incursão no universo poético ou musical (Schwarz 1988: 135). Se vale um palpite, talvez ele tenha mesmo ficado famoso fazendo letras, como acreditava. O que importa é que, se o empreendimento marginal o deixou descapitalizado, sua entrada no mercado fonográfico fez com que "ganhasse dinheiro com seu trabalho" (Schwarz 1988: 135). A essa altura, Cacaso reconhece que retomar o "hábito antigo" de escrever letras de música lhe garantiu a "profissionalização" que para o "poeta que faz livros é um negócio quase impensável” (1981: 07). Foi talvez, neste momento, que tenha acreditado que "sua vida de intelectual e artista seria mais livre compondo letras de música popular do que dando aulas na faculdade" (Schwarz 1988: 135). Daí a "qualificação profissional”, que viria através de sua defesa de tese na USP, ter "perdido todo o sentido" (Brito 1981: 07). A poesia, que agora é encarada de forma "descompromissada", assegura, como diz Cacaso, um bem que lhe é muito precioso: a "gratuidade da atividade criadora" (1981: 07).

\section{DO PÁSSARO INCUBADO AO GALO AMANHECIDO}

Se há alguma presença constante na obra poética de Cacaso, mais acentuadamente nas duas primeiras, A Palavra Cerzida e Grupo Escolar, é a imagem das aves. Elas surgem de várias formas, seja através de pássaros e andorinhas, galos e tico-ticos ou gaivotas e urubus. Se as aves figuram em diferentes metáforas poéticas, sua força alusiva só faz acentuar a densidade semântica dos versos de Cacaso.

"O pássaro incubado", poema de abertura de A Palavra Cerzida, introduz a voz de um poeta iniciante que busca um lugar para aninhar-se na moderna tradição poética. 
Seu canto, à procura de afinação, constrói-se cantando. Sua entoação, já em muito singular, conquistará força em seus livros posteriores. Como pássaro arisco, o poeta ainda "é aurora que não se arrisca" (1967: 23). É "pássaro" engaiolado, "não é dono de onde mora", "nem mora onde é inquilino" (1967: 18). Qual seria o lugar do pássaro? Seus versos, formalmente bem acabados, ciscam na tradição poética do modernismo. Nesse primeiro momento, o diálogo com poetas como Murilo Mendes, João Cabral, Manuel Bandeira, Cecília Meireles e Bruno Tolentino sinaliza uma fase que é de formação e de maturação latentes. Tal como "pássaro incubado", o poeta choca sua poesia "inacabada", vestindo "roupa(s)" alheias (1967: 17). Se a apropriação de outras vozes, em certa medida, determina sua poesia, nesse sentido não há como fugir da "gaiola", prisão necessária, que moldou suas primeiras penas. A passagem pela tradição poética modernista configura-se penosa, porém vital - o poeta "habita cada momento que existe dentro do cubo"- e sabe "ser duro" (1967:17). Será na dureza, na resistência à voz da tradição e, posteriormente da censura, que Cacaso alcançará seu canto mais vívido. Apesar de sua poesia ainda configurar-se ao lado de outros cantos, ela já se define na opção pelo "meio", pela multidão. Tal qual andorinha, o poeta não quer cantar pelas "arestas", sozinho. Acalenta a fuga, sonhando com a liberdade fora do "domínio" da gaiola tradicional que "lhe decepa as asas". Quando alçar vôo livre, estará no mundo, não como "geógrafo quase alheio", "encubado" e protegido, mas como "nervo exposto" (1967: 77) Nesse sentido, Cacaso afirma sua poética pelo negativo: talvez ainda não tenha muita certeza do que deseja, mas certamente conhece o que não quer. Embora a metáfora do pássaro engaiolado seja lugar-comum na literatura brasileira, é bom lembrar que em meados de 66/67 ainda havia possibilidade de liberdade de expressão entre os artistas. Se o golpe de 1964 "pegou o país em um momento de grande agitação cultural", o período mais complicado da ditadura militar ainda estava por vir (Brito, 1997: 103-104). O galo, como figura transgressora, também aparece neste livro. Destituído de sua função universal de anunciar o dia, o "galo amanhece" enquanto o dia “canta no terreiro" (1967: 23). O estranhamento poético, suscitado pela inversão da ordem do mundo, anuncia uma poesia que se fará por constantes deslocamentos. Pelo canto do galo fala o poeta "em tempo de notícia": "sou mapa e não me desvendo" (1967: 33). O "geógrafo" convertido em mapa, precisa decifrar-se, aprender geografia. Em outras palavras: se o aprendizado poético é também existencial, a poesia capta um 
momento único de ser e estar no mundo. Momento talvez "inútil", diz o poeta ressentido com a passagem do tempo em "Anulação". Através do tempo, o poeta se reinventa: "Me invento na laje/ no corte/ e na palavra. Inútil: estou sempre recomeçando" (1967: 39). Recomeçar parece ser palavra de ordem em Cacaso. E será de outro lugar que ele voltará à cena poética em seu livro seguinte, Grupo Escolar.

\section{A GAIVOTA E O TICO-TICO}

O "resgat(e) do mundo posto à margem", anunciado em "Alegorias", último poema de A Palavra Cerzida, parece sinalizar a necessária "transform(ação)" do poeta “em verbo" (1967: 167). O tom altivo do primeiro livro cede lugar, em Grupo Escolar, ao coloquial, marcado pela ironia corrosiva - praticamente inexistente no livro de 1967 - e a uma poesia mais comprometida com as vivências cotidianas. Na foto de um cartaz que abre o livro de 1974, lemos: “divirta-se à vontade". O livro, dedicado ao filho Pedro, que nascera em 1971, introduz uma novidade. Além do contínuo aprendizado poético - vejam que o poeta volta aos bancos escolares - assistimos à sua iniciação paterna. Ambos os fatos organizam a estrutura interna do livro que é divido em quatro partes-“lições"- correspondentes às quatro séries do antigo grupo - intercaladas por nove fotos de seu filho (serão os nove meses de gestação?). Além das fotos de Pedro, encontramos também fotos de cenas de rua que dizem bastante sobre o Brasil da época. Não é com certa tristeza que observamos que muitas dessas fotos continuam atuais, assim como algumas situações precárias denunciadas pela poesia, como as de "Logias e Analogias" (No Brasil a medicina vai bem/ mas o doente ainda vai mal...). Em bem poucos momentos, parece haver certa queda de voltagem literária dos versos que acabam virando uma espécie de veículo de denúncia das mazelas sociais. Mas quase sempre Cacaso acerta na escolha de procedimentos literários que têm grande rendimento poético, como a alegoria, para dizer sobre um Brasil à margem, que escapa dos binóculos oficiais. Como dissemos, o aprendizado poético continua, o que fica claro através dos cinco poemas iniciais, "Cartilha(s)", cada um correspondendo a uma vogal. O "poema anfíbio" continua construindo-se no embate com a tradição. Porém, agora a voz do outro soa menos conformada e mais deturpada. Em alguns poemas, atiça-se a paródia contra a paródia, e o mapa, agora "mundi” e desvendado, "viaja/ entre suspiros de amor". Uma "gaivota bissexta" cruza os ares do poema, e como o poeta, "desova a tarde" que é poesia (1974: s/p). O pássaro incubado de então transforma-se em gaivota. 
Em liberdade, alça vôos mais altos e pode pôr seus ovos. É sintomático observar como o pássaro manteve-se fiel ao apelo do galo. O recrudescimento da censura, decorrente do AI-5 em dezembro de 1968, se amedronta metaforicamente o canto do pássaro, por outro lado, o fortalece. Se é premente voar mais alto, como as gaivotas, e "já sem resistência resist(ir)", também é urgente assegurar a estratégia do tico-tico: dele ninguém rouba o fubá. Ou como diz a letra de "Lero-Lero": "Diz um ditado/ natural da minha terra/ bom cabrito é o que mais berra/ onde canta o sabiá/ desacredito/ no azar da minha sina/ tico-tico de rapina/ ninguém leva o meu fubá" (1982: 169). De rapina são mesmo algumas poesias de Cacaso que aparecem neste Grupo Escolar. É através da estratégia de apropriação da voz alheia, atualizada em tempo de "Brasil político", como diz Ferreira Gullar, que as poesias ganham fôlego maior (de cabrito?). Drummond, Gonçalves Dias, Oswald de Andrade se comparecem em raros momentos do segundo livro, surgem não como vozes impositivas de certa tradição poética, mas para fortalecer a autoria de um tico-tico que ousou desafinar o canto coletivo. Só mesmo sendo especialista em aves para fugir de tantas e tamanhas arapucas...

\section{OBRAS CITADAS}

BRITO, Antônio Carlos de. 1967. A Palavra Cerzida. Rio de Janeiro: José Álvaro. . 1974. Grupo Escolar. Rio de Janeiro: Frenesi.

. 1981. Coleção Remate de Males 2 - Rebate de Pares (revista). Org. Berta Waldman e Iumna Maria Simon. Instituto de Estudos da Linguagem, UNICAMP, Campinas. 6-9. . 1982. Mar de Mineiro. Rio de Janeiro.

1997. Não Quero Prosa. Org. e Seleção Vilma Arêas. Campinas: Editora da UNICAMP, Rio de Janeiro: Editora da UFRJ, 1997.

$1415-9767$.

2000. Revista Inimigo Rumor: Especial Cacaso. Rio de Janeiro, maio. ISSN:

HOLLANDA, Heloisa Buarque de. 2000. Vida de Artista. In: Gaspari, E., Hollanda, H. B., Ventura, Z.Cultura em Trânsito: da Repressão à Abertura. Rio de Janeiro: Aeroplano. 239-242.

LANDIM, Pedro. 2000. Carinho Eterno. In: Revista Inimigo Rumor: Especial Cacaso. Rio de Janeiro, maio. 113-114. ISSN: 1415-9767. 
SOARES, D. R. O Ornitólogo e a Arapuca: notas sobre a palavra cerzida e grupo escolar de Cacaso

PEREIRA, Carlos Alberto Messeder. 1981. Retrato de Época: Poesia Marginal Anos 70. Rio de Janeiro: FUNARTE.

SCHWARZ, Roberto. 1998. O Poeta dos Outros. Revista Novos Estudos CEBRAP, no. 22. São Paulo, outubro. 135-156. 


\title{
Poema em Prosa e Modernidade Lírica
}

\author{
Antônio Donizeti Pires (UNESP/Araraquara)
}

RESUMO: Este trabalho pretende refletir sobre a história, a teoria, a crítica e a prática do poema em prosa, cujos primeiros esboços se delineiam no Romantismo alemão. Contudo, é no âmbito da literatura francesa que o poema em prosa adquire foros de legitimidade, quando então se caracteriza como modalidade poética transgressora e revolucionária, em compasso com a própria noção de modernidade lírica e fazendo jus, mesmo, à época prosaica que o viu nascer. Sendo, sobretudo, ritmo e imagem, analogia e ironia (nos termos de Octavio Paz), o poema em prosa contribuiu para uma nova consciência e para um novo estatuto do poético, na França e alhures.

PALAVRAS-CHAVE: Poema em prosa; Poesia lírica; Modernidade; Literatura moderna.

\begin{abstract}
This paper intends to reflect on the history, theory, criticism and practice of the prose poem, whose first outlines were delineated during the German Romanticism. However, it is within the ambit of French literature the prose poem acquires legitimacy when it is characterized as a transgressive and revolutionary poetic style, in syntony with the concept of lyrical modernity while honouring the prosaic epoch which saw its birth. By being, above all, rhythm and image, analogy and irony (in words of Octavio Paz), the prose poem contributed to a new awareness and a new status of the poem in France and other places.
\end{abstract}

KEYWORDS: Prose poem; Lyrical poetry; Modernity; Modern literature.

Um

Na contra-mão da revolução utópica, progressista e reformista do longo processo de modernização que o Ocidente tem levado a efeito, a revolução às avessas engendrada pela poesia moderna é caracterizada, essencialmente, pela recuperação da magia ancestral, que invade a linguagem, o fazer poético, a concepção de poesia e o estatuto do poeta. Porém, contraditoriamente, os poetas da modernidade apresentam "a crescente necessidade, especificamente moderna, de [...] intelectualizar a poesia" (FRIEDRICH 1991: 50). Nova epistéme calcada na dissonância, na auto-suficiência e na teleologia, na aguda intelectualidade, no divórcio com a realidade, no hermetismo, na pesquisa formal, na metalinguagem e na intertextualidade exacerbadas, na fantasia ditatorial do poeta e na exploração de seu eu profundo, a poesia da modernidade, na opinião de Hugo Friedrich, quer-se apreciada e valorada por categorias negativas. 
Esses aspectos contraditórios da modernidade lírica são acirrados no poema em prosa, que, ao valer-se da revolução formal e temática propugnada pelo Romantismo, pelo Simbolismo e pela vanguarda, também se insere na tradição da ruptura preconizada por Octavio Paz em Los hijos del limo (1974) e em A outra voz (1990). Ao subverter velhas concepções e ao colocar em xeque a versificação tradicional e os conceitos arraigados de prosa e poesia, o poema em prosa, ao lado de outras conquistas técnicas e expressionais (o verso livre, o estilhaçamento do verso na página, o monólogo interior, a poesia como gnose do eu), contribuiu para uma nova consciência e um novo estatuto do poético.

O poema em prosa não é uma forma fixa, como o soneto, e sua natureza livre e essencialmente proteiforme desencoraja qualquer definição apriorística. Contudo, a obra pioneira de Suzanne Bernard, Le poème en prose de Baudelaire jusqu'à nos jours (1959), procura contornar tais questões espinhosas e, ao mesmo tempo, oferece uma conceituação bastante válida do poema em prosa em geral. Para a autora, "le poème en prose est une organisation au second degré de la prose, une 'forme secondaire', si l'on veut, formant un tout et complète en soi, un univers fermé un poème" (BERNARD 1959: 430; grifos da autora). Bernard recusa a noção do poema em prosa como híbrido e o qualifica como "un genre de poésie particulier, qui si sert de la prose rythmée à des fins strictement poétiques" (1959: 434). Esse novo gênero - ou melhor, essa nova modalidade da poesia lírica - impinge à prosa corrente, lógica, fluente, denotativa e cotidiana, de primeiro grau, suas leis estéticas específicas, caracterizadas por Bernard como "totalité d'effet, concentration, gratuité, intensité" (1959: 439). Por outro lado, o poema em prosa renuncia ao verso, à rima e à metrificação e se fundamenta sobre a união dos contrários, prosa e poesia, de cuja tensão inerente brotam os pares de opostos aproveitados por Bernard na conceituação estética do poema em prosa: a) primeiramente, este se estrutura sob um duplo princípio, poistoma seus elementos estruturais à prosa e se constrói como poema; b) em conseqüência, é o resultado da tensão entre a anarquia ou negação destrutiva, que refuta os elementos tradicionais da poesia, e a vontade de organização artística, de maneira nova e livre; c) as duas formas básicas do poema em prosa, na tradição francesa, são o poema formal ou artístico (Bertrand, os parnasianos), mais estrito, e o poemailuminação ou anárquico (Rimbaud, Lautréamont, os surrealistas), que estilhaça os 
limites, as convenções e as noções de ordem, lógica, razão, estrutura, consciência, tempo, espaço, duração... Este se configura, por excelência, como o modus privilegiado de expressão da modernidade, pois exacerba tanto o ritmo e as imagens caóticas, dilaceradas e fragmentadas do inconsciente do poeta, quanto o ritmo e as imagens caóticas, dilaceradas, absurdas e fragmentadas do mundo exterior, em constante metamorfose. Em que pese à funcionalidade, pode-se criticar a estética fechada do poema em prosa proposta por Suzanne Bernard porque esta compromete o caráter heterogêneo e aberto dessa nova modalidade de poesia lírica.

As qualidades inerentes ao poema em prosa, objeto construído de linguagem, são as mesmas do poema em versos tradicional, seja este em forma fixa, seja em versos livres e brancos, pois qualquer poema que mereça realmente o epíteto explora a condensação da linguagem e se perfaz como um todo orgânico, autônomo, fechado em si mesmo como uma esfera: o poema em prosa éo óleo essencial da arte (Huysmans); é o resultado da crise do verso (Mallarmé) que perpassa a poesia finissecular oitocentista; é uma questão de alquimia verbal (Rimbaud), de unidade de efeito(Poe), de expressão da modernidade (Baudelaire), de trabalho com a linguagem, de consciência criativa e de liberdade do poeta. Em suma, o poema em prosa revela-se campo propício para a exploração dos prismas fundamentais da lírica, conforme Ezra Pound: logopéia, fanopéia e melopéia.

Em termos formais, dos vários elementos concernentes ao poema tradicional (verso, metro, estrofe, rima, ritmo e imagem), com exceção do verso e do metro, todos os outros são encontráveis, transfigurados, no poema em prosa. Assim, abolidos o verso e o metro - substituídos por sentenças breves e/ou longas e pelo parágrafo mais distendido da prosa, de certo modo equivalente à estrofe -, constata-se que a rima convencional também é superada, agora explorada em nuanças possíveis pela homofonia (aliteração, assonância, figuras de harmonia, repetições), que explora o estrato fônico e apóia o ritmo. As imagens veiculadas pelo poema em prosa - as do mundo medieval, fantástico e grotesco de Bertrand; as do mundo moderno baudelairiano; as dissonantes de Rimbaud e Lautréamont; as evocações espirituais e interiores dos simbolistas, como em "Asas..." e "Oração ao sol”, de Cruz e Sousa (de Evocações e Missal, respectivamente) - são deliberadamente sugestivas. Conforme 
Suzanne Bernard, "cette esthétique de la suggestion, elle est, au fond, inséparable de l'esthétique même du poème en prose" (1959: 72). O poema em prosa, enfim, deixando de lado entraves maiores como o verso e a metrificação, relativizando o emprego da rima e da estrofe, valoriza essencialmente o ritmo(interior e exterior; analógico e dissonante) e a imagem (interior e exterior; analógica e dissonante) da esfacelada vida moderna e da fragmentação do artista. E ritmo e imagem, como se sabe, são os alicerces sobre os quais se edificaram as dúbias torres da lírica da modernidade.

\section{Dois}

De modo geral, as origens do poema em prosa ligam-se à importância que a prosa poética adquire, com o Pré-Romantismo e o Romantismo alemães, para a expressão de um novo estado de alma, uma nova concepção de mundo e um novo modo de perquirição do eu, do inconsciente, da natureza. Na França, tal prosa poética aparece em gérmen nas traduções da Bíblia, nasPensées de Pascal, na oratória de Bossuet, nas máximas de La Rochefoucauld. É exemplar na epopéia em prosa Télémaque (1699), de Fénelon, cuja Lettre à l'Académie (1714) questiona a rigidez do verso tradicional e o engessamento a que a poética clássica constrangera a poesia francesa do século XVIII. À prosa poética pré-romântica e romântica (penso nas divagações de Rousseau, nos romances de Chateaubriand), somam-se as traduções em prosa, para o francês, de poetas alemães, escandinavos, escoceses e ingleses, bem como as pseudotraduções - poemas geralmente escritos em prosa, sob a vaga e a voga ossiânicas de James Macpherson, como se fossem traduções de outros autores, geralmente exóticos e/ou distantes no tempo e no espaço: asChansons Madécasses (1787), de Parny, por exemplo, são breves peças em prosa que, segundo o autor, foram traduzidas do malgache.

É em tal conjuntura que aparecem em revistas de Lyon, desde 1826, os primeiros textos de Aloysius Bertrand (1807 - 1841), considerado o iniciador da poesia em prosa na lírica francesa e aquele que a decanta de seus elementos mais prosaicos, dando-lhe forma artística mais definida e definitiva. O manuscrito de Bertrand, Gaspard de la nuit, vendido ao editor Renduel em 1836, foi publicado em 1842 e traz como subtítulo a expressão "Fantaisies à la manière de Rembrandt et de Callot". Décadas depois, os parnasianos se voltarão para o formalismo pitoresco e pictórico de Bertrand. 
Charles Baudelaire (1821 - 1867), na segunda metade do século XIX, procura aplicar, na pintura da modernidade urbana, o mesmo procedimento que Bertrand aplicara ao fantástico-pitoresco da Idade Média. Mas Baudelaire, para tanto, rompe o estreito quadro-poema de Bertrand e, conforme se lê em sua carta-prefácio a Arsène Houssaye, inventa "o milagre de uma prosa poética, musical, sem ritmo e sem rima, flexível e desencontrada o bastante para adaptar-se aos movimentos líricos da alma, às ondulações do devaneio, aos sobressaltos da consciência" (BAUDELAIRE 1996: 23 25). Seus poemas em prosa aparecem esparsamente em revistas em 1855, 1857 e 1862, sendo reunidos em livro, postumamente, em 1869, sob o título Petits poèmes en prose Le spleen de Paris.

Baudelaire, como se sabe, não é ainda um poeta simbolista, mas suas reflexões estéticas, sua poesia em versos (Les fleurs du mal - 1857) e sua recolha de poemas em prosa desbravaram os caminhos para o Simbolismo e, evidentemente, para parte considerável da poesia moderna. No que tange especificamente ao poema em prosa, este será o modelo da plêiade simbolista através de duas direções principais: a do lirismo pessoal, possível com a invenção de uma nova linguagem (Rimbaud, Mallarmé), e a temática de inspiração urbana e contemporânea, evidente em Charles Cros ou nos Croquis parisiens $(1880 ; 1886)$ de J. - K. Huysmans.

Os poemas em prosa de Arthur Rimbaud (1854 - 1891) estão coligidos em Une saison en enfer(publicado em Bruxelas, em 1873) e em Illuminations, cujos textos, escritos provavelmente entre 1873 e 1875, aparecem primeiro na revista Vogue em 1886 e, logo em seguida, numa plaquetteapresentada por Paul Verlaine. Tais poemas em prosa são exemplares da alquimia do verbo e daalucinação das palavras (RIMBAUD 1998: 161;165) exploradas pelo poeta, questões estas que se tornam claras na segunda das Cartas do vidente, endereçada a Paul Demeny em 15 de maio de 1871: “Je dis qu'il faut être voyant, se faire voyant. Le poète se fait voyant par un long, immense et raisonné dérèglement de tous les sens" (RIMBAUD 1956: 306; grifos do autor). $\mathrm{Na}$ mesma carta, Rimbaud afirma que o poeta moderno, "vraiment voleur de feu" (307), deve "trouver une langue" (idem) que lhe possibilite, através do processo alquímico de depuração e da liberdade ampla e irrestrita no trato com a palavra, refletir sobre a poesia e exprimir o caos de seu eu profundo, conscientemente fragmentado. Em outras 
palavras, a partir da con-fusão das percepções sensoriais, da intuição, da sugestão, da ironia e da analogia, o poeta traz à tona seu inconsciente, revelando-o em imagens fulgurantes e originais. Daí a necessidade de uma nova linguagem poética (simbólica e simbolista, analógica e dinâmica), que ofereça, simultânea e instantaneamente, em cortes rápidos, o interior e o exterior, o passado, o presente e o futuro, o natural e o artificial, o sórdido e o sublime, o eu e o outro.

Suzanne Bernard ressalta o caráter revolucionário da poesia de Rimbaud, de crucial importância na configuração do poema em prosa. Assim, entre o formalismo estrito de Bertrand e o poema em prosa solto, prosaico e irregular de Baudelaire, Rimbaud "a trouvé le point d'équilibre, et donné au poème en prose 'intense e rapide' ses lettres de noblesse poétique" (BERNARD 1959: 210).

No século $\mathrm{XX}$, os surrealistas também cultuarão o poema em prosa e prezarão Rimbaud como um de seus principais precursores. Outros poetas, como Max Jacob, René Char e Francis Ponge - os dois últimos, em menor ou maior grau, herdeiros do Surrealismo -, se destacam no panorama da poesia lírica francesa em prosa, moderna e contemporânea. Max Jacob (1876 - 1944), por exemplo, abre seu livro Le cornet à dés (1916; 1923 - edição definitiva) com um prefácio sibilino e sugestivo, como a própria essência do poema em prosa: este, concebido como objeto construído, exige a efetiva participação do leitor, que deve ser transplantado. Jacob escreve ainda, em 1922, uma Art poétique que fundamenta sua obra, marcada pelo diálogo intertextual crítico, irônico e paródico com Bertrand, Baudelaire e Rimbaud, em constante atualização da tradição inventiva do poema em prosa. Francis Ponge (1899 - 1988), com Proêmes (1948), cria, através do neologismo, uma expressão eficaz - adotada depois por Octavio Paz - para qualificar sua poesia.

\section{Três}

Fora da França, no final do século XIX, é principalmente a partir da obra de Baudelaire que o poema em prosa atinge as várias literaturas ocidentais. Assim, além das traduções e paráfrases, o culto a Baudelaire levou à exploração e à experimentação de novas formas de expressão, elegendo-se o poema em prosa como veículo 
privilegiado: na América hispânica, Rubén Darío e Julián del Casal; em Portugal, João Barreira; no Brasil, Raul Pompéia, Cruz e Sousa e os simbolistas.

No Brasil, conquanto se possa rastrear as origens do poema em prosa na segunda geração do Romantismo, mais especificamente na obra menor de Vitoriano Palhares, As noites da virgem(Paris, 1868), ou na terceira parte da Lira dos vinte anos (1853), de Álvares de Azevedo (1831 - 1852) - cujo "Eutanásia” é a única experiência do poeta no gênero -, é mais acertado afirmar que o poema em prosa, entre nós, adquire melhor feição com as Canções sem metro de Raul Pompéia (1863 - 1895). Escritas a partir de 1883, quando o escritor cursava Direito em São Paulo, foram publicadas esparsamente na imprensa paulista, carioca e paranaense, e apareceram em livro apenas em 1900. As Canções sem metro, cujo título é sinônimo mesmo de Poemas em prosa, sofreram várias versões e conservam na fatura o rigor formal que sempre preocupou o escritorartista que foi Raul Pompéia, inclusive n'O Ateneu. Em suma, as Canções sem metro apresentam certa dubiedade (já trazida à tona, aliás, no texto de 1901 com que Venceslau de Queirós saúda o aparecimento do livro): pois os poemas, nitidamente aparentados, no rigor e na forma estrita, à experiência de Aloysius Bertrand e ao quadro-poema parnasiano, não deixam de ser profundamente tocados pela figura tutelar de Charles Baudelaire (veja-se, por exemplo, a seção "Vibrações", onde o poeta explora as correspondências entre cores, sons e sentimentos). Com isso, antecipam temas, motivos e preocupações que nortearão depois nossos poetas simbolistas. Além disso, coerentes com outras produções de Pompéia, as Canções sem metro apresentam, como tema recorrente, certo pessimismo à Schopenhauer.

Durante a vigência do Simbolismo, como se sabe, o poema em prosa vive seu apogeu na literatura brasileira. Mas por essa época, com exceção de Cruz e Sousa, que soube plasmar sua cosmovisão, expor seu eu profundo e definir os contornos de sua arte poética em textos memoráveis de Missal (nitidamente mais solar e brilhante, esteticista e impressionista) eEvocações (nitidamente mais noturno e soturno, metafísico e expressionista), pode-se dizer que a maioria dos poetas prendeu-se aos vezos da escola ao explorar, de forma superficial e rebuscada, os lugares-comuns decadentistas e simbolistas. Esses poetas, desconhecedores das experiências de Rimbaud, Mallarmé, Laforgue ou Lautréamont e, por outro lado, presos em excesso ao verniz nefelibata 
português, atulharam sua linguagem pretensamente nova com nebulosidades fosforescentes, imagens bíblicas e litúrgicas, acessórios florais, astrais, medievais, cabalísticos e de joalheria, numa profusão decididamente recusada pelos poetas modernistas. Tal pletora pirotécnica falsamente simbolista explica, pelo menos em parte, a crítica ferrenha ao poema em prosa no Brasil e o fato de as futuras gerações de poetas terem-no praticado com parcimônia.

Mas a parcimônia modernista - ou, melhor dizendo, sua sábia economia -, se faz com que o poema em prosa surja apenas esparsa e esporadicamente, lhe confere vasto campo de experiências, refinado humor, ferina ironia, constante diálogo intertextual com a tradição e um tom reflexivo que se coadunam à melhor poesia de nosso Modernismo. Veja-se, pontualmente, Bandeira, Drummond e Mário Quintana.

Na cena contemporânea, o poema em prosa exprime muito bem os anseios pósmodernos dos poetas norte-americanos, que pelo menos desde a década de 60 a ele têmse dedicado com afinco (Russell Edson, Michael Benedikt, Charles Simic), escrevendo suas obras e publicando antologias onde se preocupam em definir - e em legitimar essa que se tornou, segundo Robert Alexander, “in Donald Hall's words, 'a dominant American literary form"' (1996: 5). De sua parte, a crítica Margueritte S. Murphy considera o poema em prosa um gênero subversivo (desde as origens), pós-moderno e dialógico por excelência. A estudiosa observa que a tradição do poema em prosa angloamericano é errática e idiossincrática, pois não teve, como na França, o fermento dos poetas românticos e simbolistas para se desenvolver. Pode-se dizer que o caminho trilhado pelo poema em prosa nas literaturas de língua portuguesa também foi irregular e particular, mas a discussão contemporânea, pelo menos no Brasil, não o considera como veículo estrito da pós-modernidade lírica. Ao contrário: o recém-publicado ensaio "Poesia e pós-modernidade", de Ricardo Araújo (em O pós-Modernismo, 2005), considera como estritamente pós-modernas as experimentações radicais da poesia visual, da vídeo-poesia ou da infopoesia. Herdeiras incontestes do Concretismo, tais formas levam ao paroxismo o arsenal estético conquistado por aquele: o apreço pelo estrato visual, a estrutura verbivocovisual, o aporte e o suporte tecnológicos, a intersemiose, o rigor, a "sobreposição do analógico ao irônico" (ARAÚJO 2005: 298). 
A meu ver, o ensaísta tem certa razão, mesmo porque o poema em prosa no Brasil nunca foi tão revolucionário quanto o foi na França (exceto, talvez, no que tange à obra de Cruz e Sousa), cabendo a nosso Modernismo e à poesia concretista, por consenso, o papel de revoluções estéticas permanentes. Contudo, vários e contraditórios são os caminhos da poesia contemporânea no Brasil, e ao lado dos herdeiros do Concretismo há os que recuperam os cacos da tradição clássica e medieval, atualizando formas, temas e motivos; e há os que fazem do poema em prosa (ao lado do poema em versos, ou mesmo da narrativa) um meio específico de construir poesia. Cito, pontualmente, as experiências de Rubens Rodrigues Torres Filho, Cláudio Willer, Zulmira Ribeiro Tavares. Com isso, o poema em prosa no Brasil adquiriu foros privilegiados de reflexão sobre a própria poesia, o poeta, o mundo, a vida e o eu, instâncias sempre sujeitas à liqüidificação contemporânea.

\section{OBRAS CITADAS}

ALEXANDER, R. et al, eds. 1996. The party train: a collection of North American prose poetry. Minneapolis: New Rivers.

ARAÚJO, R. 2005. Poesia e pós-modernidade. In: GUINSBURG, J., \& BARBOSA, Ana Mae, org. O pós-modernismo. Stylus 12. São Paulo: Perspectiva. 295-314.

BAUDELAIRE, C. 1996. Pequenos poemas em prosa. Tradução de Dorothé de Bruchard. Florianópolis: UFSC.

BERNARD, S. 1959. Le poème en prose de Baudelaire jusqu'à nos jours. Paris: Nizet.

CRUZ E SOUSA, J. da. 1995. Obra completa. Rio de Janeiro: Nova Aguilar.

FRIEDRICH, H. 1991. Estrutura da lírica moderna. São Paulo: Duas Cidades.

MURPHY, M. S. 1992. A tradition of subversion: the prose poem in English from Wilde to Ashbery. Massachusetts: $\mathrm{U}$ of Massachusetts $\mathrm{P}$.

PAZ, O. 1974. Los hijos del limo: del romanticismo a la vanguardia. Barcelona: Seix Barral. . 2001. A outra voz. São Paulo: Siciliano, 2001. 1996. Signos em rotação. Debates 48. São Paulo: Perspectiva.

POMPÉIA, R. 1982. Canções sem metro. Vol. 4. Rio de Janeiro: Civilização Brasileira/OLAC. 
PIRES, A. D. Poema em Prosa e Modernidade Lírica

POUND, E. 1989. ABC da literatura. São Paulo: Cultrix.

RIMBAUD, A. 1956. Oeuvres. Paris: Mercure de France. 1 998. Prosa poética. Rio de Janeiro: Topbooks. 


\section{Por uma Compreensão Poética da Memória (Adélia Prado e Astrid Cabral)}

Angélica Soares (UFRJ)

RESUMO: Reflexões sobre a memória e o discurso literário memorialístico em diálogo com poemas selecionados de Adélia Prado e Astrid Cabral que, se constituindo como metamemória, desvelam a natureza ilimitável da memória; tornando improcedente fragmentar o tempo em momentos estanques; demarcar fronteiras entre percepção e imaginação, realidade e ficção; limitar o sujeito da recordação a uma concepção fechada. Imagens adelianas de $O$ coração disparado remetem para a indestrutibilidade do que se constrói pela memória e para o seu sentido simbólico e comemorativo. Em Lição de Alice, Cabral recria humanos pré-sentimentos apontando para a mobilidade temporal, o caráter inventivo e a ação geradora da memória. Nessas obras, surpreendem-se proustianos signos sensíveis da memória, edificantes do re-cordar.

PALAVRAS-CHAVE: Adélia Prado; Astrid Cabral; memória

ABSTRACT: Reflections on the memory and the reminescent literary speech in dialogue with selected poems of Adélia Prado and Astrid Cabral that, built as metamemory, reveal the unlimited nature of memory; it is improper to break up the time in stanched moments, to demarcate borders between perception and imagination, reality and fiction, to limit the subject of the memory to a closed conception. Adelian images of the $O$ coração disparado send for the indestructibility of that if it constructs for the memory and for its symbolic and commemorative direction. In Lição de Alice, Cabral recreates human pre-feelings pointing with respect to secular mobility, the inventive character and the generating action of the memory. In these books, one may be surprised by proustian sensible signs of the memory, edifying remembrances.

KEYWORDS: Adélia Prado; Astrid Cabral; memory

Ao voltar-me para a compreensão da memória e do memorialismo literário, definições e conceitos me pareceram insuficientes; daí ter optado por buscar diálogos possíveis com textos poéticos selecionados, que me permitissem introduzir a permanente tensão entre lembrar e esquecer, pensada, aqui, como um dos pilares do nosso dinamismo existencial.

Neste trabalho, detenho-me na leitura de poemas de $O$ coração disparado, de Adélia Prado e Lição de Alice, de Astrid Cabral, nos quais pude detectar a configuração de uma metamemória, uma vez que neles, a memória poematizada conduz à uma 
reflexão sobre a sua própria dinâmica. Assim, ela faz-se objeto do poema, deixando-nos vestígios de seu mostrar-se e retrair-se, promotores da historicidade humana: de tudo o que o ser humano é e faz, em sua temporalidade unitária, tridimensional, simultaneamente presente, passado e futuro (SOARES, 2004, p. 300-1).

Em $O$ coração disparado, Adélia Prado ressalta, superlativamente, a natureza afetiva e mágica da memória quando se refere, no poema intitulado "A casa", a uma “casa de esquina”, não localizável geograficamente, como habitação reconstruída memorialisticamente:

É um chalé com alpendre, forrado de hera.

Na sala, tem uma gravura de Natal com neve.

Não tem lugar pra esta casa em ruas que se conhecem.

Mas afirmo que tem janelas,

claridade de lâmpada atravessando o vidro,

um noivo que ronda a casa

- esta que parece sombria -

e uma noiva lá dentro que sou eu.

É uma casa de esquina, indestrutível.

Moro nela quando lembro,

quando quero acendo o fogo,

as torneiras jorram,

eu fico esperando o noivo, na minha casa aquecida.

Não fica em bairro esta casa

infensa à demolição.

Fica num modo tristonho de certos entardeceres,

quando o que um corpo deseja é outro corpo pra escavar.

Uma idéia de exílio e túnel. (PRADO 1987: 24)

A memória habita, liricamente, o poema adeliano e, como lhe é próprio, "sensível a todas as transferências (...) se enraíza no concreto, no espaço, no gesto, na imagem, no objeto" (NORA 1993: 9); daí, a fruição de cada detalhe, que conduz ao mergulho do sujeito nos seus mais sinceros desejos. Assim, nos é possível visualizar cenas e projeções do interior para o exterior e vive-versa, no movimento de imersão das coisas no sujeito e de emersão do que lhe vai de mais íntimo: movimentos que acabam por se inter-relacionar, “... num modo tristonho de certos entardeceres”. Esses motivadores involuntários da memória, mobilizam a busca erótica de "continuidade do ser" (BATAILLE 1980: 17; 91-2), que ocorreria pela penetração de um corpo em outro 
corpo. E lembremos, mais uma vez ,com Pierre Nora, que a verdadeira memória se abriga também "nos saberes do corpo" (NORA 1993: 14).

Em Adélia Prado, a casa é a casa, onde não há limites para a fantasia e para o desconhecido e é, ainda, o lugar do "exílio", que se quer compartilhado, pois "o que um corpo deseja é outro corpo pra escavar". E o que se espera escavar no outro é uma travessia, uma passagem, um "túnel” para a vida. Essa casa existe e é "indestrutível", porque construção de memória ("infensa à demolição").

No universo adeliano, em "ruas que se desconhecem", situa-se a morada da memória, uma vez que ela penetra o inconsciente, com suas dimensões incapturáveis a nos deixarem a sensação da falta e das lacunas intraduzíveis pela palavra. E porque a memória resguarda o silêncio, o que se edifica por ela não se esgota e não se destrói. Possuidora de uma força incalculável, sustenta uma permanência que não se deixa controlar; como diria Nora, "susceptível de longas latências e de repentinas revitalizações" (NORA 1993: 9). A “casa aquecida" de Adélia Prado nos oferece uma experiência instigantemente poética, iluminada pelo vigor revitalizante da memória, com a simbólica "claridade de lâmpada atravessando o vidro", desnudando transparências insuspeitadas.

Adélia Prado parece-nos querer lembrar, com as lições heideggerianas, que "poeticamente o homem habita" (HEIDEGGER 2002: 165-81) quando vivencia a essência do habitar (HEIDEGGER 2002: 127), construindo-se e questionando-se em sua humanidade.

A consciência adeliana da memória, como um modo fugidio de experienciação, que é inalienável da existência humana, se explicita também em $O$ coração disparado, no poema, cujo título "Subjeto" nos parece preservar a idéia do que se lança de baixo, dos recônditos territórios do inconsciente para a consciência: em associações espáciotemporais de objetos, lugares, sensações etc. que o recordador parece querer conservar tais quais foram vividas e / ou imaginadas e, ao mesmo tempo, quer transmiti-las com palavras, embora saiba que estas as deformam, por conformá-las sempre diferentemente: 
O cheiro da flor de abóbora, a massa de seu pólen, para mim, como óvulo de coelhas.

- Vinde zangões, machos tolos, picar a fina parede que mal segura a vida, tanto ela quer viver.

Ainda que não vos houvesse eu fecundaria essas flores com meu nariz proletário. - Ora, direis, um lírio ignóbil.

Pois vos digo que a reproduzo em ouro sobre meu vestido de núpcias, meu vestido de noite. Dentro do quarto escuro, ou na rua sem lâmpadas, de cidade ou memória, um sol.

Como pequenas luzes esplêndidas. (PRADO 1987: 27)

Em "Subjeto", como em toda a escrita poematizada da memória, o verso, cortando as frases, expõe os cortes entre o vivido ou o possivelmente vivido e o narrado, de forma predominantemente lírica, abrindo-se sulcos transversais para a passagem do imaginário e, com ele, o trânsito para o sentido simbólico das imagens relembradas que, acionadas pela imaginação, reúnem, muitas vezes, o que nos poderia parecer sem nenhuma relação aparente, não fosse o significado emocional e existencial que têm elas para o recordador.

E como não atentar para a impossibilidade de se criarem fronteiras entre memória e imaginação? Cabe-nos reconhecer, conforme sintetizou Eduardo Portella, o caráter inventivo da memória: "C'est une invention d'ont la memoire nous fournit elle même la matière première.” (2003: 3). A força da memória está, mesmo, em sua inclinação para metamorfosear-se e recriar-se. Manuel de Barros, em seu poema "As lições de R. Q.”, integra memória e criação ao reconhecer a humana necessidade de "transver o mundo". Em verso antológico, ele registra o ato de transvisão, que diz melhor dessa natureza imaginativa da memória: "O olho vê, a lembrança revê, e a imaginação transvê" (BARROS 1997: 75); uma vez que o que ficou para trás, se torna irresgatável em sua realidade palpável, assim como o que, na memória, já se projeta para o futuro. Transver é, pois, a própria experiência do acontecer memorante.

$\mathrm{Na}$ imaginação, incidem o alargamento do pensar, o risco da irrealidade, a previsão e até a vigília para a possibilidade de algo relacionado aos acontecimentos presentes e passados. Relaciona-se, assim, comumente à idéia do inexistente. Por outro lado, é a capacidade para criar algo que, ganhando forma, se torna possível, pois há uma 
força prospectiva na imaginação, pela qual temos acesso a uma presentificação do ausente, a partir do percebido. Perceber e imaginar são atos simultâneos e se impregnam mutuamente embora, comumente, tentemos diferençá-los. O que Adélia Prado parece nos dizer é tudo isso e não só. É que na ação de lembrar contamos com a imaginação, pois que os fatos não se revivem, reconstroem-se, recriam-se nos descontínuos e lacunares movimentos temporais da rememoração. E assim é porque há "necessidade de basear a vida complexa numa pluralidade de durações que não têm nem o mesmo ritmo, nem a mesma solidez de encadeamento, nem o mesmo poder de continuidade" (BACHELARD 1988: 7) atendendo à diversidade dos fenômenos temporais, percebida na tarefa de seriar os seus diferentes planos. A linearidade de um tempo único para todos os fenômenos, os resume sempre de forma imperfeita.

Desse modo, a recordação do que estaria subjacente na memória caminha, direcionada pelas forças geradoras das sensações, da "flor de abóbora" com o seu "pólen" para a "fecundação", as "núpcias", o "quarto escuro" ou a "rua sem lâmpadas", que se iluminam pelo "ouro" da "flor de abóbora", já agora bordada no "vestido de noite", a resplandecer como um sol, conjugando todas as "pequenas luzes esplêndidas" e aí o valor esplendoroso do que poderia aparecer como um "lírio ignóbil" é o que se preserva. E, se essa "rua" é "de cidade ou de memória" não importa. O que importa para a recordadora é a natureza solar do seu desejo simples e "proletário" de viver e de produzir vida.

Em sua dimensão metamemorialística, o poema explicita, ainda, a postura adeliana de dramatização da memória, que dinamiza a interação, desde sempre existente no memorialismo poético, entre narração e lirismo. Em "Subjeto", o lírico se associa ao narrativo e ao dramático e, assim, todas as dimensões do humano se juntam para trazer à tona fragmentos que permitem reconstituir a vida fragmentada pela cronologia.

Os discursos diretos ou indiretos do sujeito, a associarem fala e gesto, impõem a forma do monólogo, que intensifica a convicção, transmitida pela recordadora, da densidade dos pequenos-grandes momentos de "luzes esplêndidas"; como também são aqueles rememorados em "Solar": "Minha mãe cozinhava exatamente: / arroz, feijão roxinho, molho de batatinhas. / Mas cantava" (PRADO 1987: 28). 
Esses são momentos epifânicos, ensolarados, que Adélia Prado conserva no exercício poético de epifania da linguagem, quando se atinge o máximo de sentido, no mínimo de palavras, deixando-se irradiar a natureza "solar" iluminadora e fecundante do silêncio, pelas entrelinhas do poema e pelas entrelinhas da memória.

Se, em "Subjeto", a poetisa de Divinópolis ressalta, de início, o poder evocativo do olfato, em "O guarda-chuva preto", o olhar se encarrega de mobilizar memória e metamemória, na construção dos versos:

Esquecido na mesa,

com o cabo voltado para cima

e as bordas arrepanhadas,

é como seu dono vestido,

composto no seu caixão.

Não desdobra a dobradiça,

não pousa no braço grave

do que, sendo seu patrão,

foi pra debaixo da terra.

Ele, vai para o porão.

Existe um retrato antigo

em que pousou aberto,

com o senhor moço e sem óculos.

Guarda-chuva, guarda-sol,

guarda-memória pungente

de tudo que foi em nós

um pouco ridículo e inocente.

Guarda-vida, arquivo preto,

cão de luto, cão jazente. (PRADO 1987: 22)

O símile do quarto verso introduz o pensar dinâmico e simultâneo na vida e na morte, porque simultâneos são seus modos de ser. A partir do mesmo verso, pela agilidade nas associações, que caracteriza o estilo adeliano, ligam-se sujeito e objeto, num processo de analogias, encadeamentos e gradações que culminam na metamorfose de um simples "guarda-chuva preto" em um "guarda-memória pungente" e, pela pungência da memória, um "guarda-vida". E, como "guarda-memória", o sujeito recordador se pluraliza e nos inclui a todos em nossa finitude. Aquele "guarda-chuva preto" passa a simbolizar, então, o "arquivo preto" de todos nós, como a querer a poetisa nos remeter para a "consciência comemorativa da memória" (NORA 1993: 12) que detém, no prefixo "com”, a sua ação como um resgate sempre comunitário, mesmo quando recomposto individualizadamente. 
Nos desdobramentos finais da "imagem-lembrança": "guarda-chuva", "guardasol”, "guarda-memória", "guarda-vida" parece-me delinear-se a atuação da memória como revelação repentina de um passado (aí gravado em "um retrato antigo") que busca presentificar-se no discurso.

$\mathrm{Na}$ forma do presente do indicativo do verbo "existir" fica textualizado o presente presentificante, a permitir que o presentificado ("o senhor moço e sem óculos") chegue até nós e nos ponha em guarda ("cão de luto, cão jazente") para a nossa transitoriedade.

Astrid Cabral, por sua vez, traz-nos o sentido da pré-visão indicado na referência ao "amanhã", remetendo-nos para a atuação geradora da memória, a promover em nós a ocorrência da antecipação. E essa antecipação revela, em últimas instâncias, o nosso modo de ser no mundo, que é o de ser-no-mundo-para a morte; o que Heidegger assim fundamentou, ontologicamente:

O "ser-aí" tem noção do tempo fugitivo porque a deduz do "fugitivo" saber de sua morte. No falar com maior ênfase do passar do tempo há um reflexo explícito do advir finito da temporalidade do "ser-aî". E por poder permanecer a morte encoberta até no falar do passar do tempo, se mostra o tempo como um passar "em si". (HEIDEGGER 1977: 458-9)

A literatura memorialística (e, por isso, inventiva) leva-nos a concluir, pelas mãos de Proust que, ao redescobrir-se o tempo, o que temos não é a representação literária do tempo vivido, mas o revelar (enquanto velar-se no desvelado) da essência temporal da realidade, que irrompe das ruínas, no impalpável do presente e no mais além do futuro, que a literatura garante em seus deslimites:

Mas quando mais nada subsistisse de um passado remoto, após a morte das criaturas e a destruição das coisas, sozinhos, mais frágeis porém mais vivos, mais imateriais, mais persistentes, mais fiéis, - o odor e o sabor permanecem ainda por muito tempo, como almas, lembrando, aguardando, esperando, sobre as ruínas de tudo o mais, e suportando sem ceder, em sua gotícula impalpável, o edifício da recordação. (PROUST 1983: 47) 
Esses proustianos signos sensíveis da memória, edificantes do re-cordar (do pôr de novo no coração) comparecem na produção literária de Astrid Cabral pela ambigüidade sensorial, na qual se alicerçam as tensões do tempo em Lição de Alice. Aí, o pré-ser-se da memória figuriza-se como "Véspera", antecedendo-se à "própria história":

Sem saber de que chafariz jorrariam as lágrimas nem de que ferida braba nasceria a cicatriz à véspera da própria história aspirávamos o amanhã flor de maçã, white magnólia. (CABRAL 1986: 88)

No modo astridiano de recriação lírica da mobilidade temporal da memória, o futuro do pretérito melhor diz da vigília do sujeito à espreita das dores inevitáveis e de suas marcas, cicatrizadas pela ação do tempo após a pré-sentida "ferida braba". Sendo assim, recorda-se um amanhã desejado e já fruído nas fragrâncias da "flor de maçã" e da "white magnólia", essências de perfumaria que testemunham o poder evocativo dos signos olfativos que se impregnam na alma e, como almas em sua imortalidade, espreitam-nos, à espera de manifestar-se. Ensinando a suportar a dor do crescimento e da finitude, a memória brinda o ser com a evasão criativa, libertadora, que nos faz esquecer, "cicatrizar" as danificações e até brincar, divertir-nos, inventar a vida, também na invenção da linguagem.

É pelo viés desse divertimento, que Astrid Cabral joga explicitamente, com as sugestões semânticas da língua e que, infantilmente (como Alice, de Carroll) prefere pensar, recriar o pensamento que pensa os mistérios do futuro, ainda não atravessados: envoltos no presente. Assim, ela une todos os tempos, em "Vesperal".

\author{
Enxerto-me no ontem: \\ eis-me à janela de gerânios \\ num recanto de Londres. \\ Um sol de sangue parafraseia-me \\ o coração sangria desatada. \\ Ainda não atravessei \\ o mistério do meu futuro. \\ (A vida, um presente no embrulho). (CABRAL 1986: 89)
}


A partir do título, instala-se a ambivalência dos signos. "Vesperal" liga-se à véspera, à tarde, à idéia de tudo o que precede um acontecimento e até à festa, a divertimento. O presente é véspera do futuro, mas também o que se ganha como regalo, com intento de agradar, de alegrar, de divertir. "Sangria desatada", como grande perda de sangue, é o que precisa de atendimento imediato: os apelos do "coração". Na inversão maneirista, o que se exprime externamente (a cor sangüínea do sol) reflete o sentimento do eu ("parafraseia-me"); o que traz ao poema, além do emblematismo natural, a consciência de que se trata de um jogo lingüístico, de um divertimento com as potencialidades da língua, na criação de novos modos de dizer. Por isso, também, por identificação com os "gerânios", o eu enxerta-se na véspera do hoje para conviver com o amanhã, ainda não desvelado.

Não se trata, portanto, apenas de reconstruir-se o passado no presente da recordação, mas de reconhecer que a memória instala uma incessante tensão com o futuro. Esta nos aparece como uma das lições da reflexividade memorialística do poema e via de acesso a uma compreensão mais abrangente da relação entre tempo e memória.

Adélia Prado e Astrid Cabral, relembradas nesta comunicação, parecem querer revelar, nas entrelinhas do texto, que também no discurso a vida se constrói e o sujeito articula, privilegiadamente, a experienciação temporal, sempre alicerçada nos ilimitáveis da memória.

\section{OBRAS CITADAS}

BACHELARD, Gaston. 1988. A dialética da duração. Trad. Marcelo Coelho. São Paulo: Ática.

BARROS, Manoel de. 1997. Livro sobre nada. 3. ed. Rio de Janeiro: Record.

BATAILLE, Georges. 1980. O erotismo. 2. ed. Trad. João Bénard da Costa. Lisboa: Moraes.

CABRAL, Astrid. 1986. Lição de Alice. Rio de Janeiro: Philobiblion.

HEIDEGGER, Martin. 1977. El ser y el tiempo. Trad. José Gaos. México: Fondo de Cultura Económica.

. 2002. Construir, Habitar, pensar. In: _. Ensaios e conferências. 2. ed. Trad. Emmanuel Carneiro Leão et aliii. Petrópolis: Vozes. 125-41. 
. 2002. ... poeticamente o homem habita. In: _. Ensaios e conferências. 2. ed. Trad. Emmanuel Carneiro Leão et aliii. Petrópolis: Vozes. 165-81.

NORA, Pierre. 1993. Entre memória e história: a problemática dos lugares. Trad. Yara Aun Khoury.Projeto história (São Paulo) 10: 7-28.

PORTELLA, Eduardo. 2003. Paradoxes de la mémoire. Diogéne (Paris) 201: 3-4.

PROUST, Marcel. 1983. No caminho de Swann. Trad. Mário Quintana. 8. ed. Porto Alegre: Globo.

PRADO, Adélia.1987. O coração disparado. 4.ed. Rio de Janeiro: Guanabara.

SOARES, Angélica. 2004. O apelo poético-memorialístico do ilimitado em Mulher no palco, de Lya Luft. In: CASTRO, Manuel Antônio de; Org. A construção poética do real. Rio de Janeiro: 7 Letras. 298-310. 